ORNL/CDIAC-148

NDP-084

\title{
CARBON DIOXIDE, HYDROGRAPHIC, AND CHEMICAL DATA OBTAINED DURING THE R/V MAURICE EWING CRUISE IN THE ATLANTIC OCEAN (WOCE SECTION A17, 4 JANUARY-21 MARCH 1994)
}

\author{
Contributed by \\ Aida F. Ríos, ${ }^{1}$ Kenneth M. Johnson ${ }^{2}$, Xosé Antón Álvarez-Salgado, ${ }^{1}$ Linda Arlen, ${ }^{3}$ André Billant, ${ }^{4}$ \\ Linda S. Bingler, ${ }^{5}$ Pierre Branellec, ${ }^{4}$ Carmen G. Castro, ${ }^{1}$ David W. Chipman, ${ }^{6}$ \\ Gabriel Rosón, ${ }^{7}$ and Douglas W. R. Wallace ${ }^{8}$ \\ ${ }^{1}$ Consejo Superior de Investigaciones Científicas \\ Instituto de Investigaciones Marinas, Eduardo Cabello, 6, 36208-Vigo, Spain \\ ${ }^{2}$ Brookhaven National Laboratory, Upton, NY, USA (retired) \\ ${ }^{3}$ James J. Howard Marine Science Laboratory, Highlands, NJ, USA \\ ${ }^{4}$ Laboratoire de Physique des Océans, CNRS-IFREMER-UBO, IFREMER/Centre de Brest, \\ B.P. 70, 29280 Plouzané, France \\ ${ }^{5}$ Battelle Pacific Northwest Laboratories, Sequim, WA, USA \\ ${ }^{6}$ Lamont-Doherty Earth Observatory, Columbia University, Palisades, NY, USA (retired) \\ ${ }^{7}$ Departamento de Fisica Aplicada, Facultad de Ciencias del Mar, University of Vigo, \\ Campus Lagoas Marcosende s/n, 36200-Vigo, Spain \\ ${ }^{8}$ Leibniz-Institut für Meereswissenschaften an der Universität Kiel, Kiel, Germany \\ Prepared by \\ Alex Kozyr \\ Carbon Dioxide Information Analysis Center \\ Oak Ridge National Laboratory \\ Oak Ridge, Tennessee, USA
}

Date Published: June 2005

Prepared for the Climate Change Research Division

Climate Change Research Division

Office of Biological and Environmental Research

U.S. Department of Energy

Budget Activity Numbers KP 1204010 and KP 1202030

Prepared by the

Carbon Dioxide Information Analysis Center

OAK RIDGE NATIONAL LABORATORY

Oak Ridge, Tennessee 37831-6335

managed by

UT-BATTELLE, LLC

for the

U.S. DEPARTMENT OF ENERGY

under contract DE-AC05-00OR22725 



\section{CONTENTS}

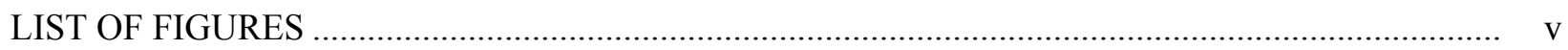

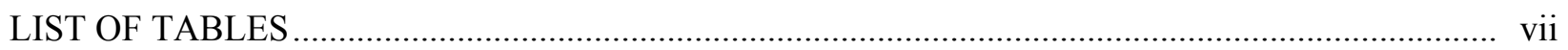

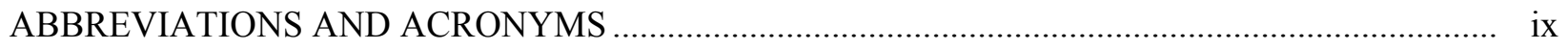

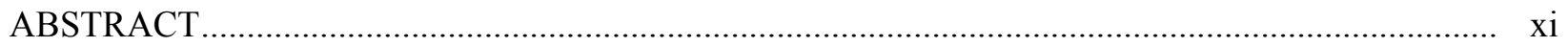

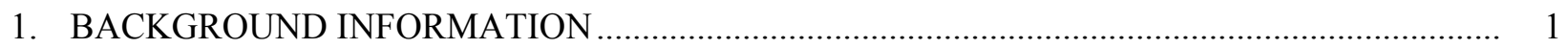

2. DESCRIPTION OF THE EXPEDITION ….................................................................. 3

$2.1 \mathrm{R} / \mathrm{V}$ Maurice Ewing: Technical Details and History …........................................................... 3

2.2 The R/V Maurice Ewing A17 Cruises Information ................................................................. 4

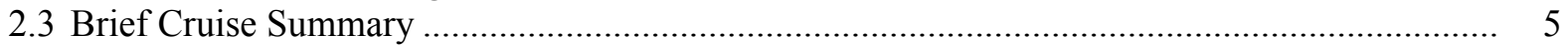

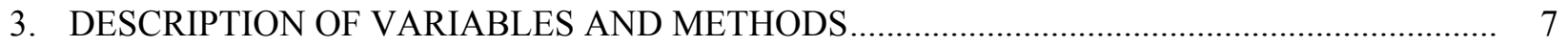

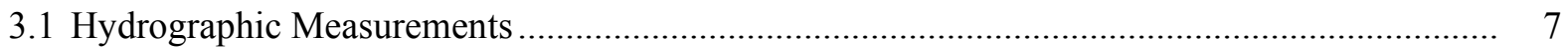

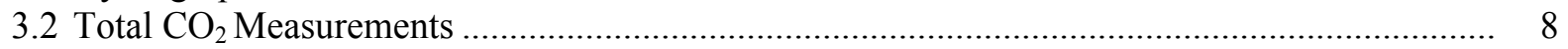

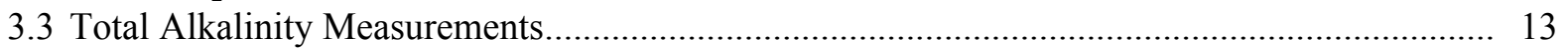

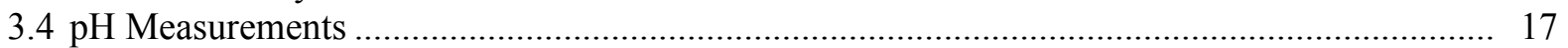

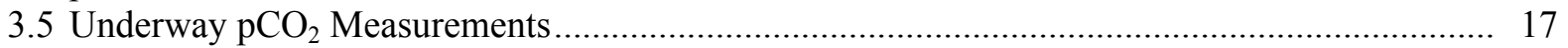

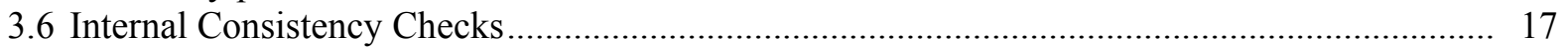

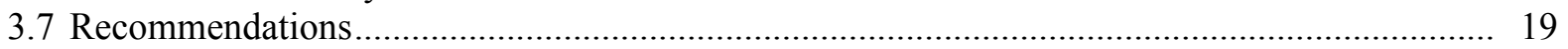

4. HOW TO OBTAIN THE DATA AND DOCUMENTATION ............................................... 23

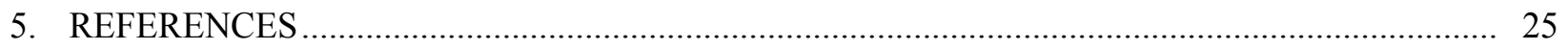





\section{LIST OF FIGURES}

Figure

Page

1.1 Cruise track during the R/V Maurice Ewing Atlantic Ocean survey expedition

along WOCE section 17

3.1 Temporal distribution of differences between measured and certified $\mathrm{TCO}_{2}$ for CRM analyzed on SOMMA-coulometry system 007 during WOCE section A17

3.2 Temporal distribution of differences between measured and certified

TALK for CRM analyzed during WOCE section A17

3.3 Relationship between normalized TALK (NTA) and silicate, both in $\mu \mathrm{mol} / \mathrm{kg}$, for the cruises CITHER-2, CITHER-3, FICARAM-2, and FICARAM-4 .

3.4 Relationship between variations of $f \mathrm{CO}_{2}$ (calculated - measured) in surface waters $\left(\triangle f \mathrm{CO}_{2}\right)$ and variations of the average $\mathrm{TCO}_{2}$ (calculated - measured) of water column data $\left(\Delta \mathrm{TCO}_{2}\right)$

3.5 Relationship between measured and calculated $\mathrm{TCO}_{2}$ from TALK and $\mathrm{pH}$ using the dissociation constants given by Lueker et al. (2000)

3.6 Relationship between $f \mathrm{CO}_{2}$ measured and $f \mathrm{CO}_{2}$ calculated from TALK and $\mathrm{pH}$ using the dissociation constants given by Lueker et al. (2000) 



\section{LIST OF TABLES}

Table

Page

2.1 Specifications of R/V Maurice Ewing ........................................................................ 3

3.1 Number of stations and samples analyzed for carbonate system variables

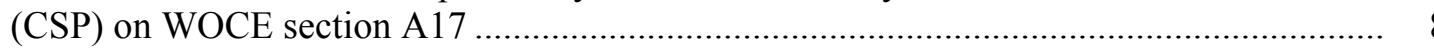

3.2 Electronic calibration and mean gas calibration coefficients for system 007 coulometer on WOCE section A17

3.3 Mean analytical difference $\left(\Delta \mathrm{TCO}_{2}=\right.$ measured - certified $)$ and the standard deviation of the differences between measured and certified $\mathrm{TCO}_{2}$ on WOCE section A17.

3.4 History and disposition of cells exhibiting unsatisfactory or outlier analytical differences $\left(\triangle \mathrm{TCO}_{2}=\right.$ measured - certified $)$ for CRM analyzed on WOCE section A17.

3.5 Precision of the discrete $\mathrm{TCO}_{2}$ analyses on WOCE section A17

3.6 $\mathrm{TCO}_{2}$ difference (ship - shore) between duplicate seawater samples analyzed in real time by coulometry (ship) and onshore by manometry at SIO

3.7 Mean analytical difference $(\triangle \mathrm{TALK}=$ measured - certified $)$ and standard deviation of differences between measured and certified TALK on WOCE section A17 



\section{ABBREVIATIONS AND ACRONYMS}

\begin{tabular}{|c|c|}
\hline $\mathrm{A} / \mathrm{D}$ & analog-to-digital \\
\hline bhp & brake horsepower \\
\hline BNL & Brookhaven National Laboratory \\
\hline${ }^{14} \mathrm{C}$ & radiocarbon \\
\hline CALFAC & calibration factor \\
\hline CDIAC & Carbon Dioxide Information Analysis Center \\
\hline $\mathrm{CFC}$ & chlorofluorocarbon \\
\hline CICYT & Comisión Interministerial de Ciencia y Tecnología \\
\hline CNRS & Centre de la Recherche Scientifique \\
\hline $\mathrm{CO}_{2}$ & carbon dioxide \\
\hline CRM & certified reference material \\
\hline CSIC & Consejo Superior de Investigaciones Cientificas, Spain \\
\hline CSP & carbon system variable \\
\hline CTD & conductivity, temperature, and depth sensor \\
\hline DIC & dissolved inorganic carbon \\
\hline DOE & U.S. Department of Energy \\
\hline$f \mathrm{CO}_{2}$ & fugacity of $\mathrm{CO}_{2}$ \\
\hline IFREMER & Institut Français de Recherche pour L'Exploitation de la Mer \\
\hline IIM.CSIC & Instituto de Investigaciones Marinas, CSIC, Vigo, Spain \\
\hline INSU & Institut National des Sciences de l'Univers \\
\hline $\mathrm{I} / \mathrm{O}$ & input/output \\
\hline JGOFS & Joint Global Ocean Flux Study \\
\hline LDEO & Lamont-Doherty Earth Observatory \\
\hline LMCE & Laboratoire de Modélisation du Climate et de l' Environnement \\
\hline LODYC & Laboratoire d'Océanographie Dynamique et de Climatologie \\
\hline LPO & Laboratoire de Physique des Océans \\
\hline NBS & National Bureau of Standards \\
\hline NDP & numeric data package \\
\hline NMFS & National Marine Fisheries Service \\
\hline NOAA & National Oceanic and Atmospheric Administration \\
\hline NODC & National Oceanographic Data Center \\
\hline NSF & National Science Foundation \\
\hline ORNL & Oak Ridge National Laboratory \\
\hline $\mathrm{pCO}_{2}$ & partial pressure of $\mathrm{CO}_{2}$ \\
\hline PNEDC & Programme National d'Etude de la Dynamique du Climat \\
\hline PNNL & Pacific National Laboratory \\
\hline
\end{tabular}




$\begin{array}{ll}\text { QA } & \text { quality assurance } \\ \text { QC } & \text { quality control } \\ \text { RB } & \text { Rio de Janeiro, Brazil } \\ \text { R/V } & \text { research vessel } \\ \text { SFB } & \text { Sonderforschungsbereich } \\ \text { SIO } & \text { Scripps Institution of Oceanography } \\ \text { SOMMA } & \text { single-operator multi-parameter metabolic analyzer } \\ \text { SSS } & \text { seawater substandard } \\ \text { TALK } & \text { total alkalinity } \\ \text { TCO } & \text { total carbon dioxide } \\ \text { TD } & \text { to-deliver } \\ \text { VFC } & \text { voltage-to-frequency converter } \\ \text { WHOI } & \text { Woods Hole Oceanographic Institution } \\ \text { WHP } & \text { WOCE Hydrographic Program } \\ \text { WOCE } & \text { World Ocean Circulation Experiment }\end{array}$




\begin{abstract}
Ríos, A., K. M. Johnson, X. A. Álvarez-Salgado, L. Arlen, A. Billant, L. S. Bingler, P. Branellec, C. G. Castro, D. W. Chipman, G. Rosón, and D. W. R. Wallace. 2005. Carbon Dioxide, Hydrographic, and Chemical Data Obtained During the R/V Maurice Ewing Cruise in the Atlantic Ocean (WOCE Section A17, 4 January-21 March 1994), ed. A. Kozyr. ORNL/CDIAC-148, NDP-084. Carbon Dioxide Information Analysis Center, Oak Ridge National Laboratory, U.S. Department of Energy, Oak Ridge, Tennessee, 39 pp. doi: 10.3334/CDIAC/otg.ndp084

This documentation discusses the procedures and methods used to measure total carbon dioxide $\left(\mathrm{TCO}_{2}\right)$, total alkalinity (TALK), and $\mathrm{pH}$ at hydrographic stations during the $\mathrm{R} / \mathrm{V}$ Maurice Ewing cruise in the South Atlantic Ocean on the A17 WOCE section. Conducted as part of the World Ocean Circulation Experiment (WOCE), this cruise was also a part of the French WOCE program consisting of three expeditions (CITHER 1, 2, and 3) focused on the South Atlantic Ocean. The A17 section was occupied during the CITHER 2 expedition, which began in Montevideo, Uruguay, on January 4, 1994 and finished in Cayenne, French Guyana, on March 21, 1994. During this period the ship stopped in Salvador de Bahia and Recife, Brazil, to take on supplies and exchange personnel. Upon completion of the cruise the ship transited to Fort de France, Martinique. Instructions for accessing the data are provided.

$\mathrm{TCO}_{2}$ was measured using a single-operator multiparameter metabolic analyzer (SOMMA) coupled to a coulometer for extracting and detecting $\mathrm{CO}_{2}$ from seawater samples. The overall precision and accuracy of the $\mathrm{TCO}_{2}$ analyses was $\pm 1.6 \mu \mathrm{mol} / \mathrm{kg}$. A second carbon system variable, TALK, was determined by potentiometric titration with an overall precision of $\pm 1.7 \mu \mathrm{mol} / \mathrm{kg}$. During the A17 cruise the carbon system was overdetermined because a third carbonate system variable, $\mathrm{pH}$, was also measured potentiometrically with an overall precision of \pm 0.003 . The underway partial pressure of $\mathrm{CO}_{2}\left(\mathrm{pCO}_{2}\right)$ in surface waters was also continuously measured along the cruise track.

A comparison of A17 TALK with recent data in the South Atlantic Ocean confirms that A17 TALK data need a downward correction of $8 \mu \mathrm{mol} / \mathrm{kg}$ that was integrated in the CDIAC database. The internal consistency study carried out among the four carbon system variables led us to adjust the $\mathrm{pH}$ measurements by stations in order to eliminate the difference between $\mathrm{TCO}_{2}$ measured and $\mathrm{TCO}_{2}$ calculated from $\mathrm{pH}$ and TALK.

The R/V Maurice Ewing A17 data set is available free of charge as a numeric data package (NDP) from the Carbon Dioxide Information Analysis Center. The NDP consists of three oceanographic data files, one FORTRAN 77 data retrieval routine file, and this printed documentation, which describes the contents and format of all files as well as the procedures and methods used to obtain the data.
\end{abstract}

Keywords: carbon dioxide, $\mathrm{TCO}_{2}$, total alkalinity, $\mathrm{pH}$, partial pressure of $\mathrm{CO}_{2}$, carbon cycle, coulometry, potentiometry, hydrographic measurements, World Ocean Circulation Experiment, meridional section, South Atlantic Ocean. 



\section{BACKGROUND INFORMATION}

The World Ocean Circulation Experiment-World Hydrographic Program (WOCE-WHP) was a major component of the World Climate Research Program. The primary goal of WOCE was to understand the general circulation of the global ocean well enough to be able to model its present state and predict its evolution in relation to long-term changes in the atmosphere. The need for carbon system measurements arose from the serious concern over the rising atmospheric concentrations of carbon dioxide $\left(\mathrm{CO}_{2}\right)$. Increasing atmospheric $\mathrm{CO}_{2}$ may intensify the earth's natural greenhouse effect and alter the global climate.

Although $\mathrm{CO}_{2}$-related measurements - specifically, total $\mathrm{CO}_{2}\left(\mathrm{TCO}_{2}\right)$, total alkalinity (TALK), partial pressure of $\mathrm{CO}_{2}\left(\mathrm{pCO}_{2}\right)$, and $\mathrm{pH}$-were not official WOCE measurements, a coordinated effort was supported as a core component of the Joint Global Ocean Flux Study (JGOFS). This effort received support in the United States from the U.S. Department of Energy (DOE), the National Oceanic and Atmospheric Administration (NOAA), and the National Science Foundation (NSF), and in Spain from the Comisión Interministerial de Ciencia y Tecnología (CICYT), for WOCE cruises through 1998 to measure the global spatial and temporal distributions of $\mathrm{CO}_{2}$ and related parameters. Goals were to estimate the meridional transport of inorganic carbon in a manner analogous to oceanic heat transport (Bryden and Hall 1980; Roemmich and Wunsch 1985; Brewer et al. 1989; Holfort et al. 1998; Alvarez et al. 2003; Rosón et al. 2003), and to build a database suitable for carbon-cycle modeling and the estimation of anthropogenic $\mathrm{CO}_{2}$ increase in the oceans. To obtain a reliable database, Wanninkhof et al. (2003) made a comparison of inorganic carbon system parameters measured in the Atlantic Ocean from 1990 to 1998, recommending small adjustments for consistency among other cruises in the zone. The $\mathrm{CO}_{2}$ survey took advantage of the sampling opportunities provided by the WOCE cruises during this period, and the final data set covered on the order of 23,000 stations. Wallace (2002) reviewed the goals, conduct, and initial findings of the global $\mathrm{CO}_{2}$ survey, and recently Sabine et al. (2004) estimated a global oceanic anthropogenic $\mathrm{CO}_{2}$ sink between 1800 and 1994.

This report discusses results of the research vessel (R/V) Maurice Ewing expedition along the WOCE Section A17, from 4 January to 21 March, 1994 (Fig. 1.1). The cruise, designated as CITHER2_1-2, was a part of the French WOCE program consisting of three expeditions focusing on the South Atlantic Ocean: CITHER 1 (1993), 2 (1994), and 3 (1995). $\mathrm{TCO}_{2}$ analysis personnel and support for this expedition were from Brookhaven National Laboratory (BNL), Lamont-Doherty Earth Observation (LDEO), and Battelle Pacific Northwest National Laboratory (PNNL). Analyses of TALK, pH, and nutrients were performed by Spanish scientists from the Consejo Superior de Investigaciones Cientificas (CSIC), Instituto de Investigaciones Marinas of Vigo. The hydrographic work was carried out by French scientists under the direction of Laurent Mémery Laboratoire d'Océanographie Dynamique et de Climatologie (LODYC), University of Pierre et Marie Curie, Paris, France.

The A17 section work will yield a map of the large-scale three-dimensional distribution of temperature, salinity, and chemical constituents, including the carbon system variables. This map will be combined with the results of the remaining French WOCE South Atlantic sections (A6, A7, A13, and A14) and the other South Atlantic WOCE sections measured by $\mathrm{CO}_{2}$ survey participants (A8, A9, A10, and A11) to provide an extensive reference data set. Knowledge of the measured variables and their initial conditions allow determination of heat and water transports as well as carbon transport and elucidate regional sources and sinks of carbon and fossil fuel carbon. Studies estimating the carbon transport and establishing the anthropogenic $\mathrm{CO}_{2}$ sources and sinks based on these data have already appeared in the literature (Holfort et al. 1998; Ríos et al. 2003). An understanding of anthropogenic $\mathrm{CO}_{2}$ uptake and transports contributes to the understanding of processes relevant to climate change. The South Atlantic A17 section was especially relevant to $\mathrm{CO}_{2}$ transport because it focused on the western boundary sections and currents, and provided a description of the water masses and their meridional evolution between $50^{\circ} \mathrm{S}$ and $10^{\circ} \mathrm{N}$ (Mémery et al. 2000). 


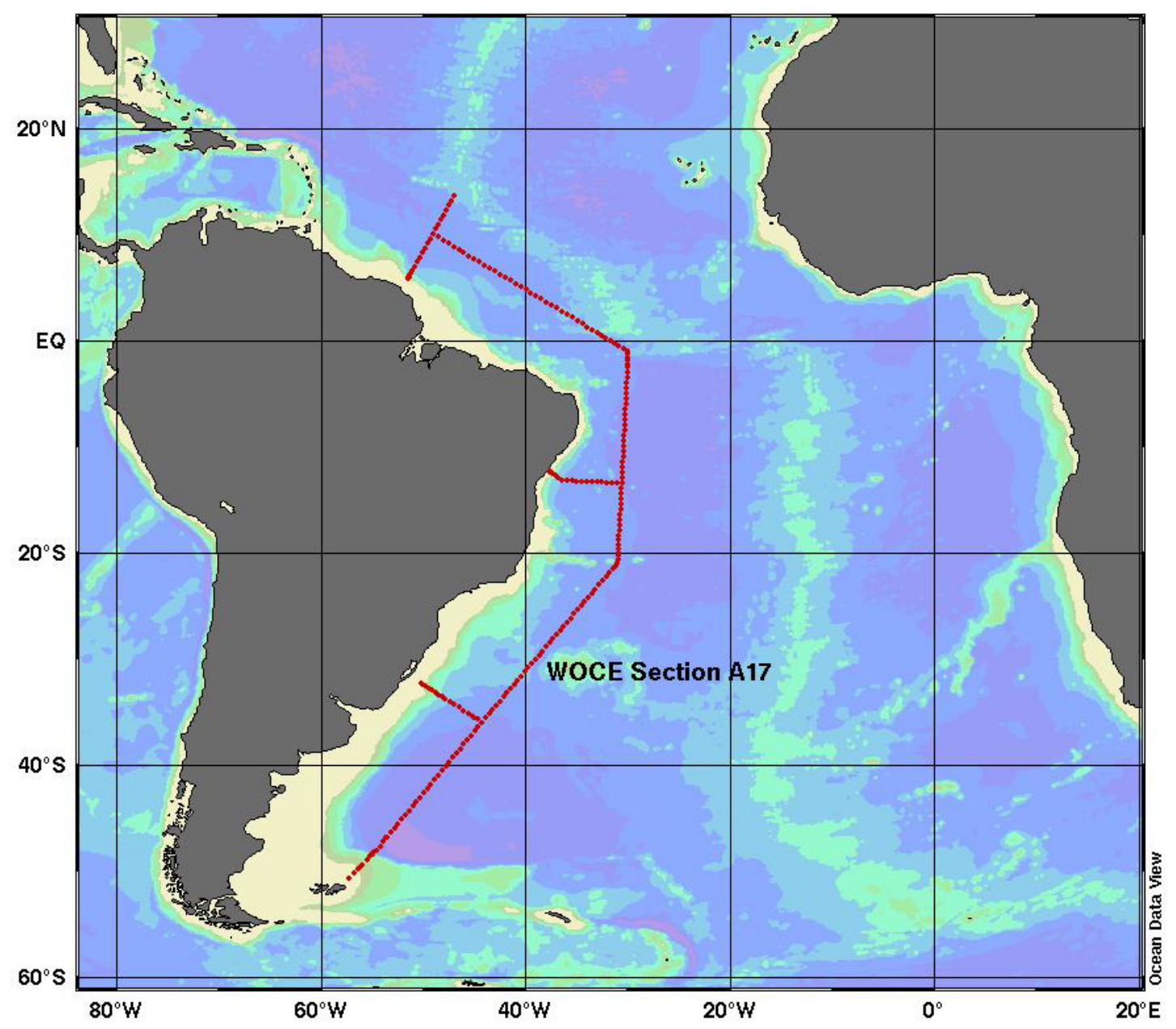

Fig. 1.1. Cuise track during the R/V Maurice Ewing Atlantic Ocean survey expedition along WOCE section A17.

The work aboard the R/V Maurice Ewing was supported by the Institut Français de Recherche pour L'Exploitation de la Mer (IFREMER; Grant 210161), the Institut National des Sciences de 1'Univers (INSU), and the Centre de la Recherche Scientifique (CNRS), in the framework of the Programme National d'Etude de la Dynamique du Climat (PNEDC) and its WOCE/France subprogram. The carbon dioxide and nutrients work was supported by DOE (DE-ACO2-76CH00016) and CICYT (Grant ANT931156-E). We would like to thank the master, officers, and crew of R/V Maurice Ewing and all the participants on the cruise CITHER-2. Special thanks go to M. Arhan, coordinator of the WOCE-France program CITHER, and L. Mémery, chief scientist of cruise CITHER 2. The authors are also especially grateful to the Sonderforschungsbereich 460 (SFB) at the University of Kiel (Dr. F. Schott, Leader), funded by the Deutsche Forschungsgemeinschaft, for their support and assistance in completing the written documentation. 


\section{DESCRIPTION OF THE EXPEDITION}

\subsection{R/V Maurice Ewing: Technical Details and History}

The R/V Maurice Ewing is a research vessel owned by the National Science Foundation (USA) and operated by the Lamont-Doherty Earth Observatory (LDEO) of Columbia University. It is classified by the America Bureau of Shipping as an A-1 and Baltic Ice Class IA ship. It was originally constructed as a seismic vessel in 1983, but it was acquired by Columbia in 1989, modified, and outfitted for tasks required of a general-purpose oceanographic research vessel. The vessel does, however, incorporate extensive and unique geophysical capabilities into its hardware; these include a Syntrak 480-24 seismic recording system, hydrophones, and sound source arrays. The vessel operates in the Atlantic, Indian, and Pacific Oceans. Table 2.1 provides a detailed description of the ship.

\section{Table 2.1. Specifications of R/V Maurice Ewing}

\begin{tabular}{|c|c|}
\hline US NODC code & 3230 \\
\hline \multicolumn{2}{|l|}{ Basic dimensions: } \\
\hline Gross registered tonnage & 1978 \\
\hline Overall length & $73.0 \mathrm{~m}$ \\
\hline Beam & $14.10 \mathrm{~m}$ \\
\hline Draught (maximum) & $5.30 \mathrm{~m}$ \\
\hline Fuel capacity & $604 \mathrm{~m}^{3}$ \\
\hline Service speed & $11.0 \mathrm{kn}$ \\
\hline Maximum speed & $13.5 \mathrm{kn}$ \\
\hline Freeboard to working deck & $2.5 \mathrm{~m}$ \\
\hline Personnel & Crew: 22 ; scientists: 28 \\
\hline Main engine (s) & $4 \times$ Diesel El at $5200 \mathrm{bhp}$ at $1200 \mathrm{rpm}$ \\
\hline Range & $17,000 \mathrm{mi}$ \\
\hline Maximum cruise duration & 60 days \\
\hline Nautical equipment & $\begin{array}{l}\text { Integrated navigation system with radar, loran, SatNav; } 3 \text { - and } \\
\text { 12-kHz echosounders (hull-mounted) for scientific research; } \\
\text { geological sonar; } 4 \text { oceanographic winches carrying } 6,000 \text { m of } \\
\text { 9/16-in. } 3 \times 19,0.68 \text {-in. coaxial cable, } 0.322 \text {-in. CTD wire, or } \\
\text { 1/4-in. } 3 \times 19 \text { wire. Hull-mounted Atlas deep ocean multibeam } \\
\text { swath bottom mapping system and electronic data processing } \\
\text { equipment (SUN computer). Ship has } 35 \text {-ton- capacity gantry, } \\
\text { 4-ton-capacity crane, and other winches for instruments or } \\
\text { sampling }\end{array}$ \\
\hline Science quarters & $\begin{array}{l}\text { Dark room, } 465 \mathrm{~m}^{3} \text { of cargo storage space, } 65 \mathrm{~m}^{2} \text { of wet } \\
\text { laboratory space, } 208 \mathrm{~m}^{2} \text { of dry laboratory space, } 30 \mathrm{~m}^{2} \text { of free } \\
\text { working deck area, science office, vehicle staging room, and a } \\
\text { small amount of container space }\end{array}$ \\
\hline
\end{tabular}




\subsection{R/V Maurice Ewing A17 Cruise Information}

$\begin{array}{ll}\text { Ship Name } & \text { Maurice Ewing } \\ \text { EXPOCODE } & \text { 3230CITHER2_1-2 } \\ \text { WOCE section } & \text { A17 } \\ \text { Ports of call } & \begin{array}{l}\text { Montevideo, Uruguay; Salvador de Bahia and Recife, Brazil; } \\ \text { Cayenne, French Guyana }\end{array} \\ \text { Dates } & \text { January 4-March 21, 1994 } \\ \text { Funding support } & \mathrm{CITHER} \text { cruise: INSU, CNRS, PNEDC, France }^{\mathrm{TCO}_{2}: \text { DOE }} \\ & \text { Alkalinity, pH, and nutrients: CICYT, Spain } \\ \text { Chief scientist } & \text { Dr. Laurent Mémery, LODYC, Paris, France }\end{array}$

Parameters measured, institution, and responsible investigators

\begin{tabular}{lll} 
Parameter & Institution & Responsible Personnel \\
\hline CTD, salinity, XBT & LODYC & L. Mémery, M. Arhan, H. Mércier \\
Nutrients & IIM.CSIC & X. Alvarez-Salgado, C. G. Castro \\
Oxygen & LPO & H. Mércier \\
$\mathrm{CFCs}$ & LODYC & L. Mémery \\
Tritium, $\mathrm{He},{ }^{14} \mathrm{C}$ & LMCE & P. Jean Baptiste \\
$\mathrm{TCO}_{2}$ & BNL/PNNL & L. Bingler, L. Arlen \\
Total alkalinity, pH & IIM.CSIC & A. F. Ríos, G. Rosón \\
Underway $\mathrm{pCO}_{2}$ & LDEO & D. Chipman \\
Brazilian observer & RB & J. A. Fontainha
\end{tabular}

\section{Participating institutions}

$\begin{array}{ll}\text { BNL } & \text { Brookhaven National Laboratory } \\ \text { IIM.CSIC } & \text { Instituto de Investigaciones Marinas, CSIC, Vigo, Spain } \\ \text { LDEO } & \text { Lamont-Doherty Earth Observatory } \\ \text { LMCE } & \text { Laboratoire de Modélisation du Climate et de 1' Environnement } \\ \text { LODYC } & \text { Laboratoire d' Oceanographie Dynamique et de Climatologie } \\ \text { LPO } & \text { Laboratoire de Physique des Océans } \\ \text { PNNL } & \text { Pacific Northwest National Laboratory } \\ \text { RB } & \text { Rio de Janeiro, Brazil }\end{array}$




\subsection{Brief Cruise Summary}

The analytical team for the $\mathrm{A} 17$ section $\mathrm{CO}_{2}$ measurements was put together as part of the Global $\mathrm{CO}_{2}$ Survey conducted during WOCE from 1990 to 1998. The A17 section covered the Argentine and Brazil deep basins from the tip of South America to the equator. The cruise took place during the height of the $\mathrm{CO}_{2}$ survey and was completed with the cooperation of an international group of scientists from the United States, Spain, and France.

Although the cruise took place aboard a U.S. ship, the R/V Maurice Ewing, the A17 section was a part of a three-year-long French hydrographic expedition (CITHER) in the South Atlantic. In order to make the $\mathrm{TCO}_{2}$ measurements on A17, four U.S. institutions had to combine forces to complete the work. The single-operator multi-parameter metabolic analyzer (SOMMA) and coulometer analytical system came from the Lamont-Doherty Earth Observatory (LDEO) at Columbia University; the $\mathrm{TCO}_{2}$ group leader L. Bingler was from Battelle's Pacific Northwest Laboratory (PNNL); the assistant $\mathrm{TCO}_{2}$ analyst L. Arlen came from the NOAA's National Marine Fisheries Service (NMFS) Laboratory in Sandy Hook, New Jersey. The training and financial support of the analysts was carried out at and provided by BNL. In addition, PNNL paid for a barometer, which was installed in the LDEO system, and supported the production of a revised instrument manual for the SOMMA-coulometer systems. The TALK was measured by A. F. Ríos and G. Rosón of CSIC, Instituto de Investigaciones Marinas of Vigo, Spain. The latter group also measured $\mathrm{pH}$, so that as a result of the $\mathrm{A} 17$ cooperative scientific effort, the carbonate system was overdetermined. Underway $\mathrm{pCO}_{2}$ was also measured by David Chipman, who installed the $\mathrm{pCO}_{2}$ equipment in Montevideo, just before the start of the expedition.

The Maurice Ewing departed Montevideo on January 4, 1994, and headed generally south in direction of the Falkland Islands, where measurements for the main section were to begin just to the north of the islands. On the way measurements for two test stations were taken. Measurements for the main southnorth section were started on January 10 beginning on the Falklands Plateau, with station intervals normally of $30 \mathrm{~nm}$ decreasing to $9 \mathrm{~nm}$ depending upon the topography. The station work was interrupted by a storm for a day during the period of January 14-15. On January 21 the ship turned northwest toward Brazil and then east to sample the Porto Alegre western boundary section, work which was completed on January 26. A storm and problems with the CTD wire and rosette interrupted the work for two days, but by January 31 the ship reached the Vema channel between the Argentine and Brazil basins, thereafter moving northward to continue the A17 section until February 10, when work at station 115 was completed. The ship then transited to Salvador de Bahia, Brazil, making two additional test stations before arriving in port on February 13. In Salvador de Bahia, French CTD and hydrographic personnel were exchanged. The $\mathrm{CO}_{2}$ and nutrients measurement groups remained on board, however.

The Maurice Ewing departed Salvador de Bahia on February 17, 1994, and commenced sampling the Salvador western boundary section. However, difficulties were again experienced with the CTD and rosette, so that the completion of measurements for the latter section was delayed by two days. Due to these problems a decision was made to transit to Recife to pick up the expert Jean Pierre Gouillou, arriving from France, who was tasked with repairing the CTD and performing the software modification. The personnel transfer was completed during the period February 24-26, and the ship continued with the station samplings. With the removal of the first $500 \mathrm{~m}$ of the CTD wire, the CTD and rosette were restored to function, and after February 28 no additional problems were noted. By March 14 the main north-south section had been completed (station no. 210), and by March 15 the last section sampling between the Mid-Atlantic Ridge and Cayenne had begun, with sampling for the last station of the cruise (no. 235) taken just out from Cayenne on March 20. Some of the scientific personnel disembarked in Cayenne on March 21, 1994, whereupon the ship left immediately for Fort de France, Martinique, where the remainder of the scientific and crew disembarked.

A SOMMA (S/N 007) with $\mathrm{CO}_{2}$ detected by coulometry was used to determine $\mathrm{TCO}_{2}$ on the A17 section. TALK was determined by potentiometric titration using an automatic potentiometric titrator, Titrino Metrohm, with separate glass and reference electrodes. The $\mathrm{pH}$ was determined potentiometrically using a Metrohm Model $654 \mathrm{pH}$ meter, a combination glass electrode, and National Bureau of Standards 
(NBS) buffers for standardization. The $\mathrm{CO}_{2}$ samples from more than $50 \%$ of the 235 CTD stations occupied during the A17 cruise were always drawn in conjunction with tracer samples (CFCs, tritium, etc.) and the standard WOCE variables (salinity, oxygen, temperature, and nutrients). As on previous cruises, not all stations could be sampled for $\mathrm{TCO}_{2}$ and TALK because of the time required for analysis of the samples (see Table 3.1 for inorganic carbon sample distribution). However, $\mathrm{pH}$ and the WOCE standard variables were measured on all samples. 


\section{DESCRIPTION OF VARIABLES AND METHODS}

\subsection{Hydrographic Measurements}

Water samples were collected using a 32-position rosette with 8-L Niskin bottles developed at the Laboratoire de Physique des Océans, IFREMER, Brest, France. The rosette was equipped with a NeilBrown Mark-III CTD-O 2 (see Brown and Morrison 1978). In order to check the pressure measurements and temperature of the CTD on board, inverse thermometers and pressuremeters, type SIS, were mounted in the Niskin bottles to be fired at the bottom. The signal of the CTD was transmitted to the hydrographic data acquisition system of the LPO. This new system, created around a UNIX work station, allowed the user to see in real time the vertical profiles of the variables measured and calculated in order to check the quality of the signal transmitted by the CTD. The set of data transmitted by the CTD with a cadence of 32 cycles per second was recorded on a diskette. After each station, the data profiles were plotted vs pressure following the procedure of Billant (1985).

At the end of each cast, a full suite of water samples were drawn in the following order: CFCs, helium, oxygen, $\mathrm{TCO}_{2}, \mathrm{TALK}, \mathrm{pH}$, nutrients, tritium, and salinity.

During the cruise 6778 samples were analyzed for salinity within 1-2 days of collection using a Guildline PORTASAL salinometer that was calibrated with standard seawater (Batch P123, $\mathrm{K} 15=0.99994)$ produced at Wormley and dated June 10,1993 . The temperature of the thermostat was fixed at $21^{\circ} \mathrm{C}$ until station 134 , and at $22^{\circ} \mathrm{C}$ from stations 135 to 235 . The precision of the salinity determination was \pm 0.002 from 181 pairs of samples taken from two rosette sampling bottles closed at the same depth. The accuracy of the bottle salinity data was \pm 0.001 .

Dissolved oxygen was determined by Winkler titration after the technique of Culberson and Huang (1987). The operational conditions and the analytical method, including the calculation of oxygen concentrations, followed the standard WOCE procedure and recommendations given by Culberson et al. (1991) in the WOCE Manual of Operations and Methods. Appropriate corrections for sample density, blanks, and volumetric expansion have been included. The precision of the analyses was $\pm 0.78 \mu \mathrm{mol} / \mathrm{kg}$ from 196 pairs of samples taken from two rosette sampling bottles closed at the same depth. In total, 6756 oxygen analyses were completed during the A17 section.

The nutrients nitrate, nitrite, phosphate, and silicate were determined on every bottle closed on the A17 section by segmented flow analysis with a Technicon II Autoanalyzer. The combined nitrate and nitrite were determined after reduction of nitrate to nitrite in a $\mathrm{Cd}-\mathrm{Cu}$ column according to the procedure of Mouriño and Fraga (1985). The method was calibrated by diluting concentrated primary standards of dried salts $\left(\mathrm{KNO}_{3}, \mathrm{KH}_{2} \mathrm{PO}_{4}\right.$, and $\left.\mathrm{SiF}_{6} \mathrm{Na}_{2}\right)$ dissolved in Milli-Q water with aged, filtered, and low-nutrient seawater and analyzing these substandards for each run of samples analyzed on the autoanalyzer. Phosphate was determined according to the procedure of Hansen and Grasshoff (1983) as modified by Alvarez-Salgado et al. (1992). The accuracy of the method was $\pm 0.01 \mu \mathrm{mol} / \mathrm{kg}$. Silicate was determined according to Hansen and Grasshoff (1983) using ascorbic acid as the reducing agent. The accuracy of the method was $\pm 0.25 \mu \mathrm{mol} / \mathrm{kg}$. Quality control and consistency of nutrient measurements can be seen in Groupe CITHER-2 (1996).

Table 3.1 summarizes the carbonate system variables measured on WOCE Section A17. 
Table 3.1. Number of stations and samples analyzed for carbonate system variables on WOCE section A17

\begin{tabular}{lcccccr}
\hline & \multirow{2}{*}{$\begin{array}{c}\text { Total } \\
\text { Parameter }\end{array}$} & $\begin{array}{c}\text { No. of stations } \\
\text { stations on } \\
\text { sampled for } \\
\text { section }\end{array}$ & $\begin{array}{c}\text { carbonate } \\
\text { system }\end{array}$ & $\begin{array}{c}\text { \% of total } \\
\text { stations } \\
\text { sampled }\end{array}$ & & \multicolumn{2}{c}{ CSP samples analyzed } \\
\cline { 6 - 7 } & 235 & 142 & 60 & 2,904 & 163 & 3,067 \\
$\mathrm{TCO}_{2}$ & 235 & 89 & 38 & 2,458 & 146 & 2,604 \\
TALK & 235 & 235 & 100 & 5,756 & 1 & 5,757 \\
pH & & & & 11,118 & 310 & 11,428 \\
Total & & & & & & Discrete \\
\hline
\end{tabular}

${ }^{a}$ Certified reference material.

\subsection{Total $\mathrm{CO}_{2}$ Measurements}

As on previous cruises, $\mathrm{TCO}_{2}$ was determined using an automated SOMMA dynamic headspace sample processor ( $\mathrm{S} / \mathrm{N}$ 007) with coulometric detection of the $\mathrm{CO}_{2}$ extracted from acidified samples. A description of the SOMMA-coulometry system and its calibration can be found in Johnson et al. 1987; Johnson and Wallace 1992; and Johnson et al. 1993. Further details concerning the coulometric titration can be found in Huffman (1977) and Johnson et al. (1985). The methods used for discrete $\mathrm{TCO}_{2}$ on WOCE sections have been extensively dealt with in previous reports (Johnson et al. 1998a) and only need to be briefly summarized.

Seawater samples were collected in 300-mL ground-glass stoppered bottles and poisoned with $100 \mu \mathrm{L}$ of a $100 \%$ saturated solution of $\mathrm{HgCl}_{2}$ to prevent biological alterations. Prior to analyses, the samples were stored in the dark and thermally equilibrated to within $2-3^{\circ} \mathrm{C}$ of the thermostatted SOMMA system (sample pipette and sample bath), which was kept at a constant temperature of approximately $20^{\circ} \mathrm{C}$. The analysis of the $\mathrm{TCO}_{2}$ samples was usually completed within $14 \mathrm{~h}$ of collection (see DOE 1994). Duplicate samples were usually collected on each cast at the surface and from the bottom waters and analyzed within the run of cast samples from which they originated. Following standard procedure, certified reference material (CRM) was routinely analyzed during the sample analyses (approximately one CRM for every 30 samples) according to DOE (1994). The CRMs were supplied by Dr. Andrew Dickson of the Scripps Institution of Oceanography, and the A17 cruise analysts were supplied with batch 18 . The certified values for batch 18 were $\mathrm{S}=35.298$ and $\mathrm{TCO}_{2}=2115.15 \mu \mathrm{mol} / \mathrm{kg}$. The $\mathrm{CRM} \mathrm{TCO} 2$ concentration was determined by vacuum-extraction and manometry in the laboratory of C. D. Keeling at Scripps Institution of Oceanography (SIO).

The SOMMA injected an accurately known volume of seawater from an automated to-deliver (TD) pipette into a stripping chamber. Following acidification of the seawater and continuous gas extraction, the resultant $\mathrm{CO}_{2}$ was dried and coulometrically titrated on a model 5011 UIC coulometer with a maximum titration current of $50 \mathrm{~mA}$ in the counts mode [the number of pulses or counts generated by the coulometer's voltage-to-frequency converter (VFC) during the titration was displayed]. In the coulometer cell, the acid (hydroxyethylcarbamic acid) formed from the reaction of $\mathrm{CO}_{2}$ and ethanolamine was titrated coulometrically (electrolytic generation of $\mathrm{OH}^{-}$) with photometric endpoint detection. The product of the time and the current passed through the cell during the titration (charge in Coulombs) was related by Faraday's constant to the number of moles of $\mathrm{OH}^{-}$generated and thus to the moles of $\mathrm{CO}_{2}$, which reacted with ethanolamine to form the acid. The age of each titration cell was logged from its birth (time that electrical current is applied to the cell) until its death (time when the current is turned off). The age was measured in minutes from birth (chronological age) and in $\mathrm{mgC}$ titrated since birth (carbon age). 
The system was controlled with an IBM-compatible PC equipped with two RS232 serial ports (coulometer and barometer), a 24-line digital input/output (I/O) card (solid state relays and valves), and an analog-to-digital (A/D) card (temperature, conductivity, and pressure sensors). The cards were manufactured by Real Time Devices (State College, PA 16803). The SOMMA temperature sensors (model LM34CH, National Semiconductor, Santa Clara, CA), with a voltage output of $10 \mathrm{mV} /{ }^{\circ} \mathrm{F}$, were calibrated against thermistors certified to $0.02^{\circ} \mathrm{F}$ prior to the cruise using a certified mercury thermometer. These sensors monitored the temperature of SOMMA components, including the pipette, gas sample loops, and the coulometer cell. The SOMMA software was written in GWBASIC Version 3.20 (Microsoft Corp., Redmond, WA), and the instruments were driven from an options menu appearing on the PC monitor. With the coulometer operated in the counts mode, conversions and calculations were made using the SOMMA software rather than having the programs and the constants hardwired into the coulometer circuitry.

The SOMMA-coulometry systems were calibrated with pure $\mathrm{CO}_{2}$. The calibration hardware consisted of an eight-port gas sampling valve (GSV) with two sample loops of known volume (determined gravimetrically by the method of Wilke et al. 1993) connected to the calibration gas through an isolation valve with the vent side of the GSV plumbed to a barometer. When a gas loop was filled with $\mathrm{CO}_{2}$ at known temperature and pressure, the mass (moles) of $\mathrm{CO}_{2}$ contained therein was calculated, and the ratio of the calculated mass to that determined coulometrically was the calibration factor (CALFAC). The CALFAC was used to correct the subsequent sample titrations for small departures from $100 \%$ recoveries (DOE 1994). The standard operating procedure was to make gas calibrations daily for each newly born titration cell (normally, one cell per day). Normally, two or three sequential gas calibrations were run per cell between the carbon ages of 3-9 mgC with the last CALFAC used for calculation of $\mathrm{TCO}_{2}$ if it was consistent with the preceding CALFAC (i.e., agreement to $\pm 0.1 \%$ or better). The mean CALFAC and the standard deviation of the mean are shown in Table 3.2. The CALFAC for system 007 remained very stable throughout the A17 section (the change in $\mathrm{TCO}_{2}$ concentration due to change in CALFAC was $0.05 \%$ or $1.0 \mu \mathrm{mol} / \mathrm{kg}$ ) over the period November 1993 through March 1994. The mean carbon age for the mean CALFAC shown in Table 3.2 was $8.9 \pm 5.1 \mathrm{mgC}$ titrated $(\mathrm{N}=73)$.

The "to-deliver" volume $\left(\mathrm{V}_{\text {cal }}\right)$ of the sample pipettes was determined (calibrated) gravimetrically in November 1993 prior to the cruise. The calibration was checked periodically (for A17, once weekly) by collecting aliquots of deionized water dispensed from the pipette into preweighed serum bottles. The serum bottles were crimp-sealed and weighed immediately during the on-shore laboratory calibrations, or returned to shore where they were reweighed on a model R300S (Sartorius, Göttingen, Germany) balance as soon as possible. The apparent weight $(\mathrm{g})$ of water collected $\left(\mathrm{W}_{\text {air }}\right)$ was corrected to the mass in vacuo $\left(\mathrm{M}_{\mathrm{vac}}\right)$ and the calibrated TD pipette volume $\left(\mathrm{V}_{\text {cal }}\right)$ was calculated by dividing $\mathrm{M}_{\mathrm{vac}}$ by the density of the calibration fluid at the calibration temperature $\left(\mathrm{t}_{\text {cal }}\right)$. For A17, $\mathrm{V}_{\text {cal }}$ was $28.9315 \pm 0.0033 \mathrm{~mL}$ at a $\mathrm{t}_{\text {cal }}$ of $19.81^{\circ} \mathrm{C}(\mathrm{N}=47)$. The sample volume $\left(\mathrm{V}_{\mathrm{t}}\right)$ at the pipette temperature was calculated for all $\mathrm{A} 17$ samples from the expression

$$
\mathrm{V}_{t}=\mathrm{V}_{\mathrm{cal}}\left[1+a_{\mathrm{v}}\left(t-t_{\mathrm{cal}}\right)\right]
$$

where $a_{\mathrm{v}}$ is the coefficient of volumetric expansion for Pyrex-type glass $\left(1 \times 10^{-5} /{ }^{\circ} \mathrm{C}\right)$, and $t$ is the temperature of the pipette at the time of a measurement. The mean pipette temperature or analytical temperature $(t)$ on the $\mathrm{A} 17$ section was $19.70 \pm 0.29^{\circ} \mathrm{C}$.

The factory-calibrated coulometer was electronically calibrated independently in the laboratory in November 1993, prior to the cruise as described in Johnson et al. (1993, 1996) and DOE (1994); and the terms $I N T_{\mathrm{ec}}$ and $S L O P E_{\mathrm{ec}}$ were obtained and entered into the software for system 007 . The micromoles of carbon titrated $(M)$, whether extracted from water samples or the gas loops, was

$$
M=\left[\text { Counts } / 4824.45-\left(\text { Blank } \times T_{\mathrm{t}}\right)-\left(I N T_{\mathrm{ec}} \times T_{\mathrm{i}}\right)\right] / S L O P E_{\mathrm{ec}},
$$


where 4824.45 (counts/ $\mu \mathrm{mol}$ ) is a scaling factor obtained from the factory calibration, $T_{\mathrm{t}}$ is the length of the titration in minutes, Blank is the system blank in $\mu \mathrm{mol} / \mathrm{min}, I N T_{\mathrm{ec}}$ is the intercept from electronic calibration in $\mu \mathrm{mol} / \mathrm{min}, T_{\mathrm{i}}$ is the time in minutes during the titration where current flow was continuous, and $S L O P E_{\mathrm{ec}}$ is the slope from electronic calibration. Note that the slope obtained from the electronic calibration procedure applied for the entire length of the titration, but the intercept correction applied only for the period of continuous current flow (usually 3-4 min) because the intercept can only be calculated from calibrated levels of current flowing continuously. The coulometer electronic calibration should not change over the duration of the cruise - shown for earlier cruises although not without some exceptions (Johnson et al. 1998b) - and system 007 was not electronically recalibrated during the A17 section. The electronic and gas calibration coefficients for system 007 are summarized in Table 3.2.

Table 3.2. Electronic calibration and mean gas calibration coefficients for system 007 coulometer on WOCE section A17

\begin{tabular}{cccccc}
\hline Period & $S L O P E_{\text {ec }}$ & $\begin{array}{c}I N T_{\text {ec }} \\
(\mu \mathrm{mol} / \mathrm{min})\end{array}$ & CALFAC (n) & St. Dev. & $\begin{array}{c}\text { Rel. st. dev. } \\
(\%)\end{array}$ \\
\hline Nov. 1993 & 0.994635 & 0.000840 & $1.005434(2)$ & 0.000230 & 0.02 \\
A17 section & 0.994635 & 0.000840 & $1.005049(73)$ & 0.000466 & 0.05 \\
\hline
\end{tabular}

For water samples, the discrete $\mathrm{TCO}_{2}$ concentration in $\mu \mathrm{mol} / \mathrm{kg}$ was calculated from

$$
\mathrm{TCO}_{2}=M \times C A L F A C \times\left[1 /\left(\mathrm{V}_{t} \times \rho\right)\right] \times \mathrm{d}_{\mathrm{Hg}},
$$

where $\rho$ is the density of sea water in $\mathrm{g} / \mathrm{mL}$ at the measurement temperature and sample salinity calculated from the equation of state given by Millero and Poisson (1981), and $\mathrm{d}_{\mathrm{Hg}}$ is the correction for sample dilution with bichloride solution (for $\mathrm{A} 17 \mathrm{~d}_{\mathrm{Hg}}=1.000333$ ).

Quality control and quality assurance (QC-QA) were assessed from the results of the $163 \mathrm{CRM}$ analyses made during the A17 section. The mean and standard deviation of the differences between the measured and the certified $\mathrm{TCO}_{2}$ (measured - certified) are given in Table 3.3, and the temporal distribution of the differences is plotted in Fig. 3.1.

\begin{tabular}{cccc}
$\begin{array}{c}\text { Table 3.3. Mean analytical difference }\left(\Delta \mathbf{T C O}_{2}=\text { measured }-\right. \\
\text { certified) and the standard deviation of the differences }\end{array}$ \\
between measured and certified $\mathbf{T C O}_{2}$ on WOCE section $\mathbf{A 1 7}$ \\
\hline $\begin{array}{cccc}\Delta \mathrm{TCO}_{2} \\
(\mu \mathrm{mol} / \mathrm{kg})\end{array}$ & $\begin{array}{c} \pm \mathrm{St} . \mathrm{dev} . \\
(\mu \mathrm{mol} / \mathrm{kg})\end{array}$ & $\mathrm{N}$ \\
\hline System & 0.26 & 1.64 & 163 \\
\hline 0.7 &
\end{tabular}

The overall accuracy of the CRM analyses was better than $1 \mu \mathrm{mol} / \mathrm{kg}$ on system 007 for the A17 section. The precision of the CRM determination is the standard deviation of the differences between the measured and certified $\mathrm{CRM} \mathrm{TCO}_{2}( \pm 1.64 \mu \mathrm{mol} / \mathrm{kg}, \mathrm{N}=163)$. The outlier results are summarized in Table 3.4. Because six of the CRMs analyzed on A17 were considered to be outliers - meaning that the analytical difference $\left(\Delta \mathrm{TCO}_{2}\right)$ between the measured and certified $\mathrm{TCO}_{2}$ exceeded $\pm 5.0 \mu \mathrm{mol} / \mathrm{kg}$ (measured - certified) - these data are not included in Table 3.4.

Throughout the WOCE work, care was taken to titrate a limited number of samples in each coulometer cell to avoid excessive cell carbon ages and coulometer-cell-solution exhaustion or failure. In actual practice, this has meant that, on average, no cell was used to titrate more than a single 36-bottle station (a cell age of $\approx 35 \mathrm{mgC}$ titrated), and experience has confirmed this practice (Johnson et al. 1998b). This convention was not followed on the A17 section because, at this point in the program, experimental 
Maurice Ewing, WOCE A17

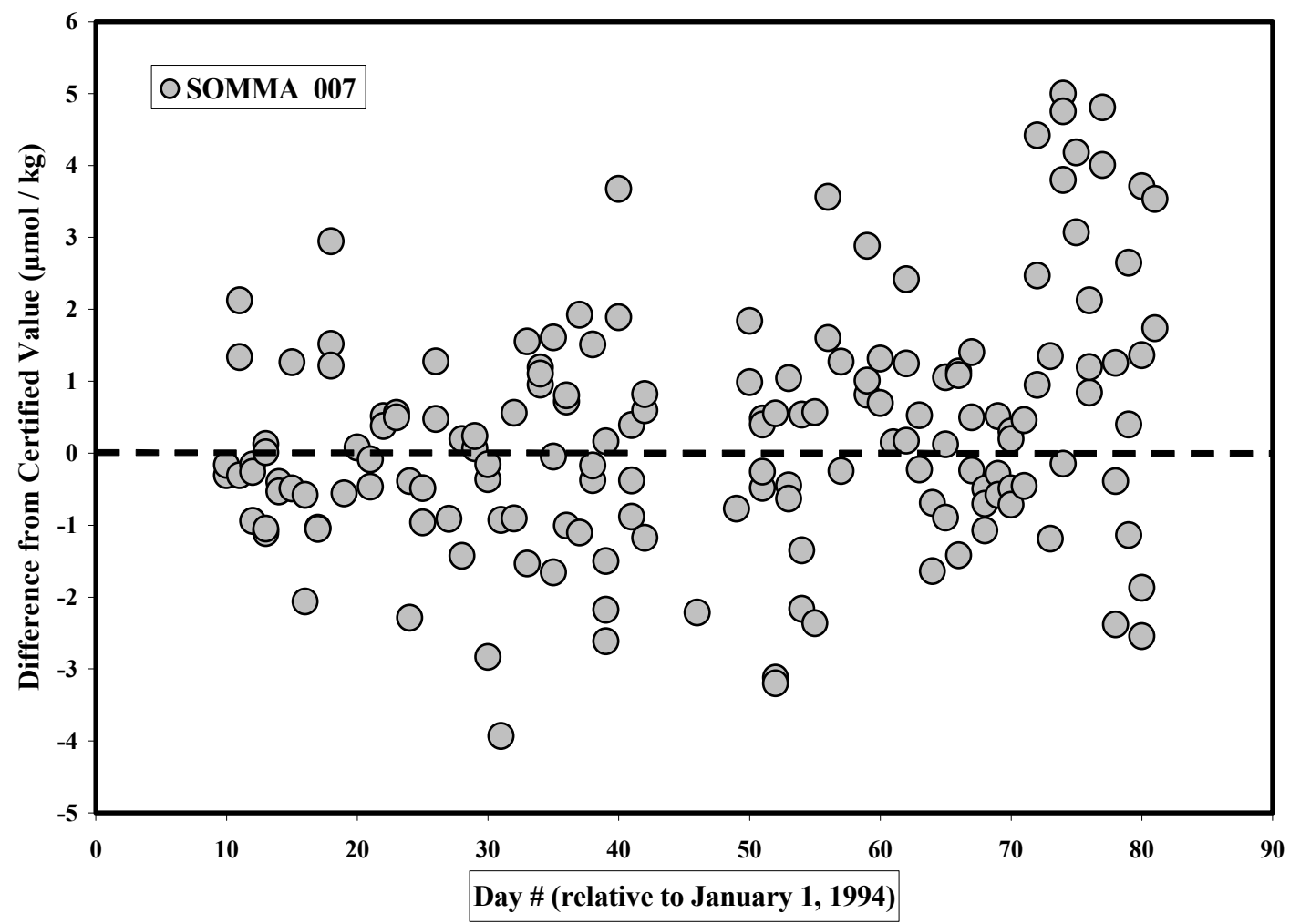

Fig. 3.1. Temporal distribution of differences between measured and certified $\mathrm{TCO}_{2}$ for $\mathrm{CRM}$ analyzed on SOMMA-coulometry system 007 during WOCE section A17. The differences were calculated by subtracting the certified $\mathrm{TCO}_{2}$ from the measured $\mathrm{TCO}_{2}$.

evidence was needed concerning the actual lifetime of the cells. Hence, the A17 cells were run so that their carbon ages (mgC titrated) routinely exceeded the $35 \mathrm{mgC}$ limit by factors of 1.5-2.5. Based on thousands of CRM analyses made during the $\mathrm{CO}_{2}$ survey and an overall precision of $\pm 1.6 \mu \mathrm{mol} / \mathrm{kg}$ for the coulometric determination of $\mathrm{TCO}_{2}$, an empirical definition of "cell failure" was proposed. Failure was defined as two successive CRM analyses with a difference $>5 \mu \mathrm{mol} / \mathrm{kg}$ on a cell whose carbon age exceeded $35 \mathrm{mgC}$. The $5 \mu \mathrm{mol} / \mathrm{kg}$ limit was chosen because it was equivalent to three standard deviations in precision. These "failures" have been designated as outliers (see Table 3.4). Table 3.4 indicates that two of the A17 cells (on 2.9 and 3.17) exhibited outliers, but that the second CRM analysis at a later carbon age with these cells was accurate. Hence, the sample data obtained with them were not flagged. For "failed" cells $(2.24,3.19$, and 3.22), a quality flag of 3-the WHPO questionable measurement flagwas assigned to those samples analyzed between the carbon age at the time of the last accurate CRM analysis and the carbon age at failure or cell death. However, based on WHPO criteria, the flagged measurements could be correct but may be open to interpretation; we have no direct evidence that they are not correct. The data shown in Table 3.4 also suggest that the original decision to set a conservative limit on cell lifetimes of $35 \mathrm{mgC}$ was sound because failures or outliers become more frequent after $35 \mathrm{mgC}$.

The second phase of the QC-QA procedure was an assessment of precision, which is presented in Table 3.5. The single-system precision was determined from samples with duplicates analyzed on system 007 . Single-system precision has been assessed in Table 3.5 as "between-sample" precision $\left(\sigma_{\mathrm{bs}}\right)$, 
Table 3.4. History and disposition of cells exhibiting unsatisfactory or outlier analytical differences $\left(\triangle \mathrm{TCO}_{2}=\right.$ measured - certified $)$ for CRM analyzed on WOCE section A17

\begin{tabular}{|c|c|c|c|c|}
\hline Date & CRM no. & $\begin{array}{c}\text { Carbon age } \\
(\mathrm{mgC})\end{array}$ & $\begin{array}{c}\Delta \mathrm{TCO}_{2} \\
(\mu \mathrm{mol} / \mathrm{kg})\end{array}$ & Comments \\
\hline 2.7 .94 & 595 & 30.3 & -8.19 & Cell terminated \\
\hline 2.9.94 & 596 & 34.4 & +11.47 & $\begin{array}{l}\text { CRM OK at } 53.2 \mathrm{mgC} \text {; no sample } \\
\text { data flagged }\end{array}$ \\
\hline 2.24 .94 & 261 & 59.4 & -6.99 & $\begin{array}{l}\text { Sample data flagged between } \\
40 \text { and } 71 \mathrm{mgC}\end{array}$ \\
\hline 3.17 .94 & 140 & 64.8 & +7.12 & $\begin{array}{l}\text { CRM OK at } 86.8 \mathrm{mgC} \text {; no sample } \\
\text { data flagged }\end{array}$ \\
\hline 3.19 .94 & 47 & 92.3 & +6.46 & $\begin{array}{l}\text { Sample data flagged between } \\
73 \text { and } 92 \mathrm{mgC}\end{array}$ \\
\hline 3.22 .94 & 441 & 65.9 & +5.91 & $\begin{array}{l}\text { Sample data flagged between } \\
45 \text { and } 71 \mathrm{mgC}\end{array}$ \\
\hline
\end{tabular}

Table 3.5. Precision of the discrete $\mathrm{TCO}_{2}$ analyses on WOCE section A17

\begin{tabular}{ccc}
\hline \multicolumn{3}{c}{ Mean absolute difference } \\
\hline $\begin{array}{c}\sigma_{\mathrm{bs}} \\
(\mu \mathrm{mol} / \mathrm{kg})\end{array}$ & $\begin{array}{c} \pm \text { St. dev. } \\
(\mu \mathrm{mol} / \mathrm{kg})\end{array}$ & $\mathrm{K}$ \\
\hline & Single-system precision \\
\hline 0.73 & 1.02 & 226 \\
\hline
\end{tabular}

which is the mean absolute difference between duplicates $(\mathrm{N}=2)$ drawn from the same Niskin bottle, where $\mathrm{K}$ is the number of samples with duplicates analyzed.

Although the single-system sample precision $( \pm 0.73 \mu \mathrm{mol} / \mathrm{kg})$ was excellent, it cannot be taken as the precision of the $\mathrm{TCO}_{2}$ determination for the $\mathrm{A} 17$ section for two reasons unique to this cruise:

1. During section A17, the replicate samples were always analyzed one right after the other. On other WOCE sections, replicate analyses were spaced such that the interval between replicates was $>3$ but $<12 \mathrm{~h}$. This was done to provide a measure of drift (change in system response) during a sequence of sample analyses on the assumption that drift would be reflected in the single-system precision by an increase in the imprecision of the duplicate analyses. Running the duplicates in sequence eliminated the possibility of detecting drift, and sample precision consequently was probably overestimated.

2. An evaluation of the samples for which duplicates were taken indicated that 10 duplicate pairs exhibited very poor precision (absolute difference between replicates from 7 to $280 \mu \mathrm{mol} / \mathrm{kg}$ ). These samples were flagged when the data set was submitted, and they are not included in the precision given in Table 3.5. Further study indicated that 9 of the 10 pairs originated from the surface rosette sample bottle (stations $8,13,25,51,61,155,177,188$, and 230) from 0 to $5 \mathrm{~m}$, and that only one pair originated from a deep bottle (5334 $\mathrm{m}$ at station 157). If the flagged results were used to calculate precision, then $\sigma_{\text {bs }}$ was $3.34 \pm 18.70 \mu \mathrm{mol} / \mathrm{kg}(\mathrm{K}=115)$ for the rosette surface bottle duplicates and $0.82 \pm 1.41 \mu \mathrm{mol} / \mathrm{kg}(\mathrm{K}=121)$ for the nonsurface bottle duplicates. These data suggested that the observed imprecision did not lay with the $\mathrm{TCO}_{2}$ measurement system. The cause was probably due to an occasional but undetected mechanical problem with the rosette, especially when the rosette bottles were closed at or near the surface. Alternatively, 
the on-deck sampling procedure at the rosette could have caused the degassing of $\mathrm{CO}_{2}$ into the Niskin bottle headspace during the time it took to draw the duplicate samples.

For the above reasons, the precision of the $\mathrm{TCO}_{2}$ determination on the $\mathrm{A} 17$ section was taken to be the standard deviation of the CRM differences (measured - certified) or $\pm 1.64 \mu \mathrm{mol} / \mathrm{kg}$ (Table 3.3) instead of the single-system precision of $\pm 1.02 \mu \mathrm{mol} / \mathrm{kg}$ given in Table 3.5.

The final step in the QC-QA procedure was the ship-to-shore comparison. Here, sample duplicates (commonly called the "Keeling samples") were analyzed in real time at sea by continuous gas extraction/coulometry and later, after storage, on shore by vacuum extraction/manometry. The Keeling samples were collected in specially provided, threaded $500-\mathrm{mL}$ glass bottles with $4 \mathrm{~mL}$ of headspace volume, poisoned with $100 \mu \mathrm{L}$ of a saturated $\mathrm{HgCl}_{2}$ solution, and then sealed airtight with a greased ground-glass stopper that was secured to the bottle with a threaded plastic screw cap. The cap was bored out to fit over the top of the stopper and mated to the bottle threads. The airtight seal was made by gently tightening the cap until a secure seal between the stopper and bottle was attained. Overtightening caused the bottles to break immediately or during transit so that considerable care and practice were required to prepare a sample that would survive the journey back to SIO. The manometric analyses for 21 samples collected from 14 stations during section A17 were completed by December 1994 in the SIO laboratory of C. D. Keeling. The results of the comparison are given in Table 3.6. The mean ship-to-shore analytical difference (ship - shore) and the standard deviation of the differences was $-0.09 \pm 1.50 \mu \mathrm{mol} / \mathrm{kg}(\mathrm{N}=21)$. This was the best agreement between the ship and shore duplicate sample analyses made by any measurement group with or without BNL-supported equipment during the entire $\mathrm{CO}_{2}$ survey. Prior to and subsequent to the A17 section, the ship-to-shore comparisons had and have consistently yielded slightly lower $\mathrm{TCO}_{2}$ values $(\cong 2 \mu \mathrm{mol} / \mathrm{kg})$ for samples analyzed in real time aboard ship compared to the reference analyses made at SIO (Wallace 2002).

Table 3.6 is particularly useful in view of the problems with surface bottle precision, which suggested the possibility of mechanical or chemical problems during rosette sampling during the A17 section. Inspection of the data in the table indicates excellent agreement between surface sample duplicates analyzed on ship and on shore and indicates that the incidence of poor precision, for whatever reason, probably did not compromise the accuracy of the $\mathrm{A}_{17} \mathrm{TCO}_{2}$ data. Indeed, Tables 3.3, 3.5, and 3.6 show that the $\mathrm{TCO}_{2}$ data set for the A17 section was internally consistent and highly accurate and precise with respect to the both the CRM, the seawater duplicate samples, and the ship-to-shore comparison seawater samples. Hence, no correction for CRM differences has been applied to the data, and the $\mathrm{TCO}_{2}$ data clearly met survey criterion for accuracy $(\leq 4 \mu \mathrm{mol} / \mathrm{kg}$ ) and precision. The reader is also referred to a recent assessment of $\mathrm{TCO}_{2}$ data quality in the Atlantic Ocean resulting from comparisons of $\mathrm{TCO}_{2}$ analyzes from crossover points sampled by different cruises between 1990 and 1998 (Wanninkhof et al. 2003).

\subsection{Total Alkalinity Measurements}

TALK was determined with a Titrino Metrohm automatic potentiometric titrator using separate glass working and reference electrodes. Potentiometric titrations were carried out in a covered but not completely closed (headspace present) titration flask to a final $\mathrm{pH}$ of 4.4 as described by Pérez and Fraga (1987a). The electrodes were standardized using an NBS buffer of $\mathrm{pH} 7.413$, checked using an NBS buffer of 4.008, and acclimated in a seawater solution buffered to a $\mathrm{pH}$ of 4.4. To determine the systematic errors produced by variations of the electrode residual liquid-junction potential, titration curves were performed each week in $\mathrm{CO}_{2}$-free seawater acidified to $\mathrm{pH} 4.0$ with hydrochloric acid as described by Culberson (1981). The titration curves were linearized, and the inverse slope was taken to represent the apparent hydrogen ion activity coefficient. The decimal logarithm difference (ranging from 0.01 to 0.06 ) between the apparent activity coefficients of the electrode and those given by Mehrbach 
Table 3.6. $\mathrm{TCO}_{2}$ difference (ship - shore) between duplicate seawater samples analyzed in real time by coulometry (ship) and onshore by manometry at SIO

\begin{tabular}{crrrrrr}
\hline Station & Date & $\begin{array}{c}\text { Niskin } \\
\text { no. }\end{array}$ & $\begin{array}{c}\text { Depth } \\
(\mathrm{m})\end{array}$ & $\begin{array}{c}\mathrm{TCO}_{2} \text { ship } \\
(\mu \mathrm{mol} / \mathrm{kg})\end{array}$ & $\begin{array}{c}\mathrm{TCO}_{2} \text { shore } \\
(\mu \mathrm{mol} / \mathrm{kg})\end{array}$ & $\begin{array}{r}\Delta \mathrm{TCO}_{2} \\
\text { Ship }- \text { shore } \\
(\mu \mathrm{mol} / \mathrm{kg})\end{array}$ \\
\hline 12 & 12.01 .94 & 14 & 3036.0 & 2260.57 & 2260.48 & 0.09 \\
30 & 18.01 .94 & 13 & 3048.0 & 2212.28 & 2217.38 & -5.10 \\
30 & 18.01 .94 & 32 & $2.0^{a}$ & 2026.70 & 2027.72 & -1.02 \\
63 & 29.01 .94 & 10 & 3060.0 & 2209.41 & 2209.67 & -0.26 \\
63 & 29.01 .94 & 32 & 4.0 & 2032.91 & 2034.28 & -1.37 \\
93 & 06.02 .94 & 12 & 2674.0 & 2174.51 & 2173.42 & 1.09 \\
93 & 06.02 .94 & 32 & 5.0 & 2062.76 & 2062.25 & 0.51 \\
114 & 11.02 .94 & 13 & 3044.0 & 2185.21 & 2184.92 & 0.29 \\
114 & 11.02 .94 & 32 & 0.0 & 2059.69 & 2059.25 & 0.44 \\
145 & 25.02 .94 & 14 & 3051.0 & 2180.87 & 2181.92 & -1.05 \\
163 & 03.03 .94 & 12 & 3248.0 & 2183.38 & 2180.82 & 2.56 \\
163 & 03.03 .94 & 32 & 0.0 & 2003.62 & 2001.88 & 1.74 \\
179 & 08.03 .94 & 32 & 0.0 & 2019.41 & 2018.74 & 0.67 \\
191 & 10.03 .94 & 11 & 3049.0 & 2174.76 & 2174.80 & -0.04 \\
204 & 13.03 .94 & 32 & 0.0 & 2021.11 & 2021.04 & 0.07 \\
210 & 15.03 .94 & 32 & 0.0 & 2020.76 & 2019.84 & 0.92 \\
215 & 16.03 .94 & 11 & 3051.0 & 2181.42 & 2180.43 & 0.99 \\
215 & 16.03 .94 & 32 & 0.0 & 2025.57 & 2025.71 & -0.14 \\
223 & 19.03 .94 & 32 & 5.0 & 2020.16 & 2021.35 & -1.19 \\
228 & 20.03 .94 & 6 & 3061.0 & 2179.78 & 2179.40 & 0.38 \\
228 & 20.03 .94 & 32 & 0.0 & 2018.21 & 2019.70 & -1.49 \\
Mean & & & & & & -0.09 \\
St. dev. & & & & & & $\pm 1.50^{b}$ \\
$\mathrm{~N}$ & & & & & & 21 \\
\hline
\end{tabular}

${ }^{a}$ The surface samples are usually the mean of two analyses. The SIO results are always mean of two analyses.

${ }^{b}$ The precision of the method was $\pm 1.64 \mu \mathrm{mol} / \mathrm{kg}$.

et al. (1973) at the same salinity and temperature with their electrode was the $\mathrm{pH}$ difference added to the final $\mathrm{pH}$ of the sample alkalinity titration to make our results equivalent with theirs using the constants of Mehrbach et al. (1973). During the cruise, the TALK of 146 CRMs from batch 18 was determined by this method. The TALK for batch 18 was not known at the time of the cruise because it was not measured during the original $\mathrm{TCO}_{2}$ certification. Subsequently, TALK was measured at SIO on archived samples from batch 18 with the value TALK $=2297.77 \mu \mathrm{mol} / \mathrm{kg}$. The mean and standard deviation of the differences between the measured and the certified TALK (measured - certified) are given in Table 3.7, and the temporal distribution of the differences is plotted in Fig. 3.2.

Table 3.7. Mean analytical difference $(\triangle T A L K=$ measured

- certified) and standard deviation of differences between measured and certified TALK on WOCE section A17

\begin{tabular}{ccc}
\hline $\begin{array}{c}\text { Mean } \Delta \text { TALK } \\
(\mu \mathrm{mol} / \mathrm{kg})\end{array}$ & $\begin{array}{c} \pm \text { St. dev. } \\
(\mu \mathrm{mol} / \mathrm{kg})\end{array}$ & $\mathrm{N}$ \\
\hline+2.13 & 1.72 & 146 \\
\hline
\end{tabular}




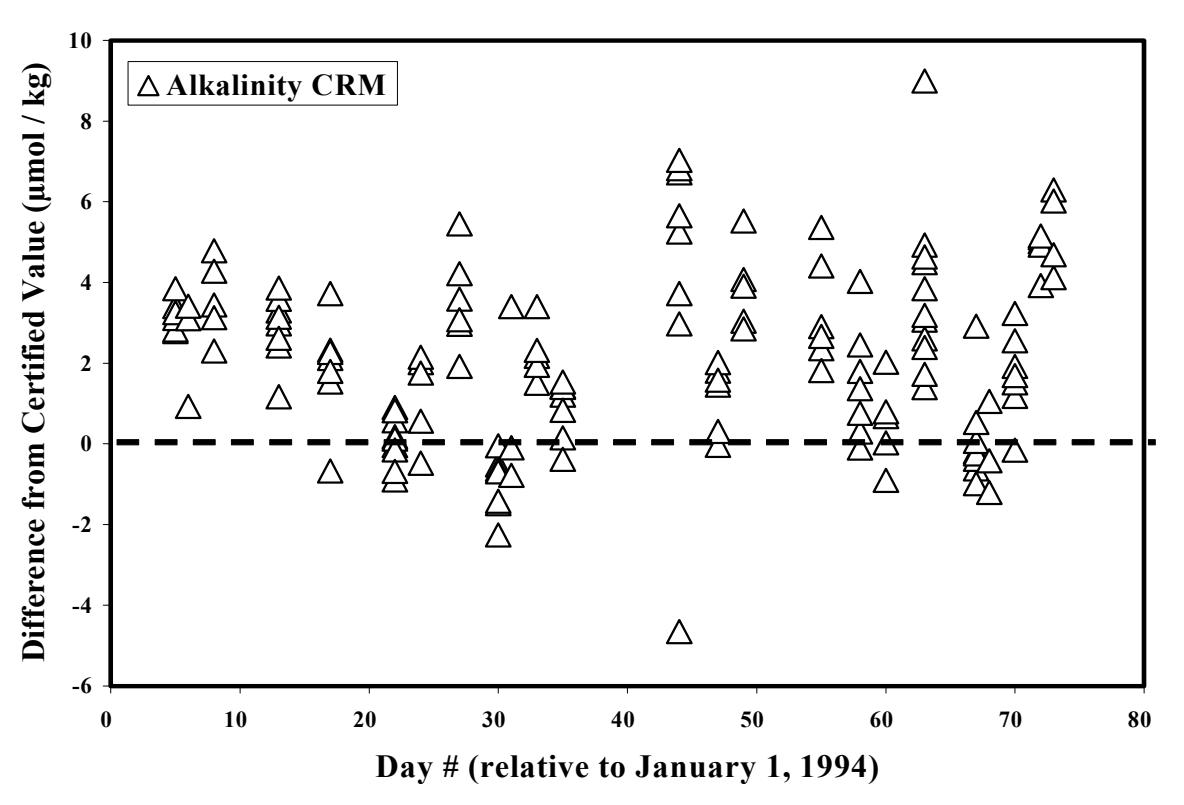

Fig. 3.2. Temporal distribution of differences between measured and certified TALK for CRM analyzed during WOCE section A17. The differences were calculated by subtracting the certified TALK from the measured TALK.

The precision of the method was assessed from 59 pairs of samples taken from two rosette sampling bottles closed at the same depth. The mean difference or precision of the TALK determination was $1.2 \pm 1.1 \mu \mathrm{mol} / \mathrm{kg}$, or approximately $\pm 0.1 \%$.

The TALK values were checked with CRMs and according to the data presented in Fig. 3.2 and Table 3.7, the mean analytical difference between measured and certified CRM was $2.1 \pm 1.7 \mu \mathrm{mol} / \mathrm{kg}$. Normally, the correction of $2 \mu \mathrm{mol} / \mathrm{kg}$ should be applied to the TALK values measured on WOCE A17 section. On the other hand, in the comparison of carbon system variables measured in the Atlantic Ocean, Wanninkhof et al. (2003) showed a deviation of $-7 \mu \mathrm{mol} / \mathrm{kg}$ with respect to A09 in the crossover analysis, but the multiple-parameter linear regression suggested that the TALK data were 5-6 $\mu \mathrm{mol} / \mathrm{kg}$ higher compared with data from other cruises in the tropical and southern regions. Wanninkhof et al. (2003) argued that the internal consistency suggested that the TALK was higher by $8 \mu \mathrm{mol} / \mathrm{kg}$; therefore, a decrease in TALK of $6 \mu \mathrm{mol} / \mathrm{kg}$ would bring the values in better agreement. However, because a decrease was suggested for A09, the bias between A17 and A09 remains of the same magnitude. Taking into account that the offset of $6 \mu \mathrm{mol} / \mathrm{kg}$ is the recommended correction, no adjustment was recommended.

In order to clarify this apparent offset, a comparison of A17 TALK data was made with WOCE A14 data obtained during the CITHER-3 cruise carried out in January and February 1995 in the eastern South Atlantic, and with recent cruises carried out following approximately the same line A17 (FICARAM II and FICARAM IV) in March and April 2001 and 2002, respectively. Figure 3.3 shows the comparison of 


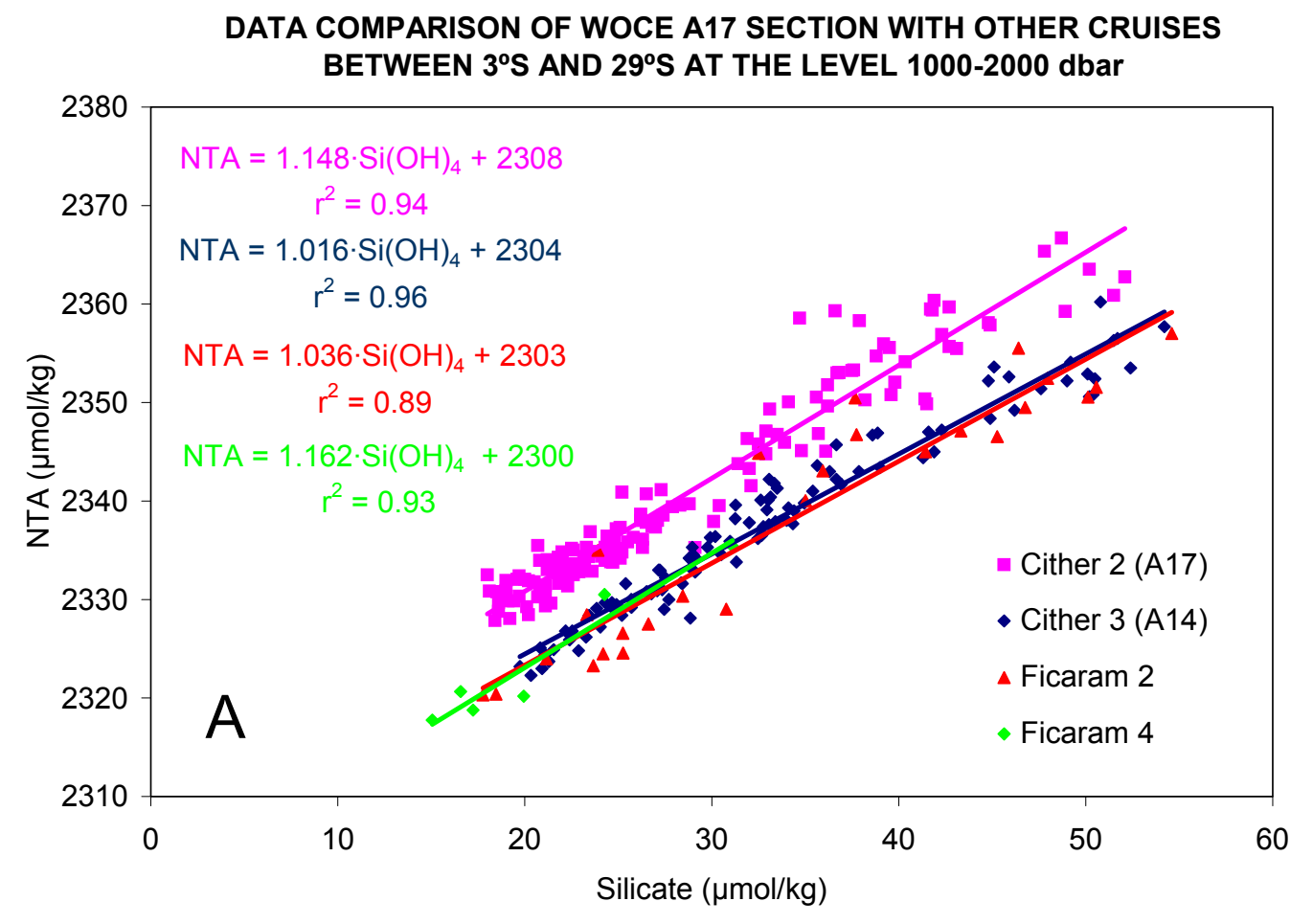

DATA COMPARISON OF SECTION WOCE A17 WITH OTHER CRUISES BETWEEN $9^{\circ} \mathrm{N}$ AND $25^{\circ} \mathrm{S}$ AT THE LEVEL 2000-3000 dbar

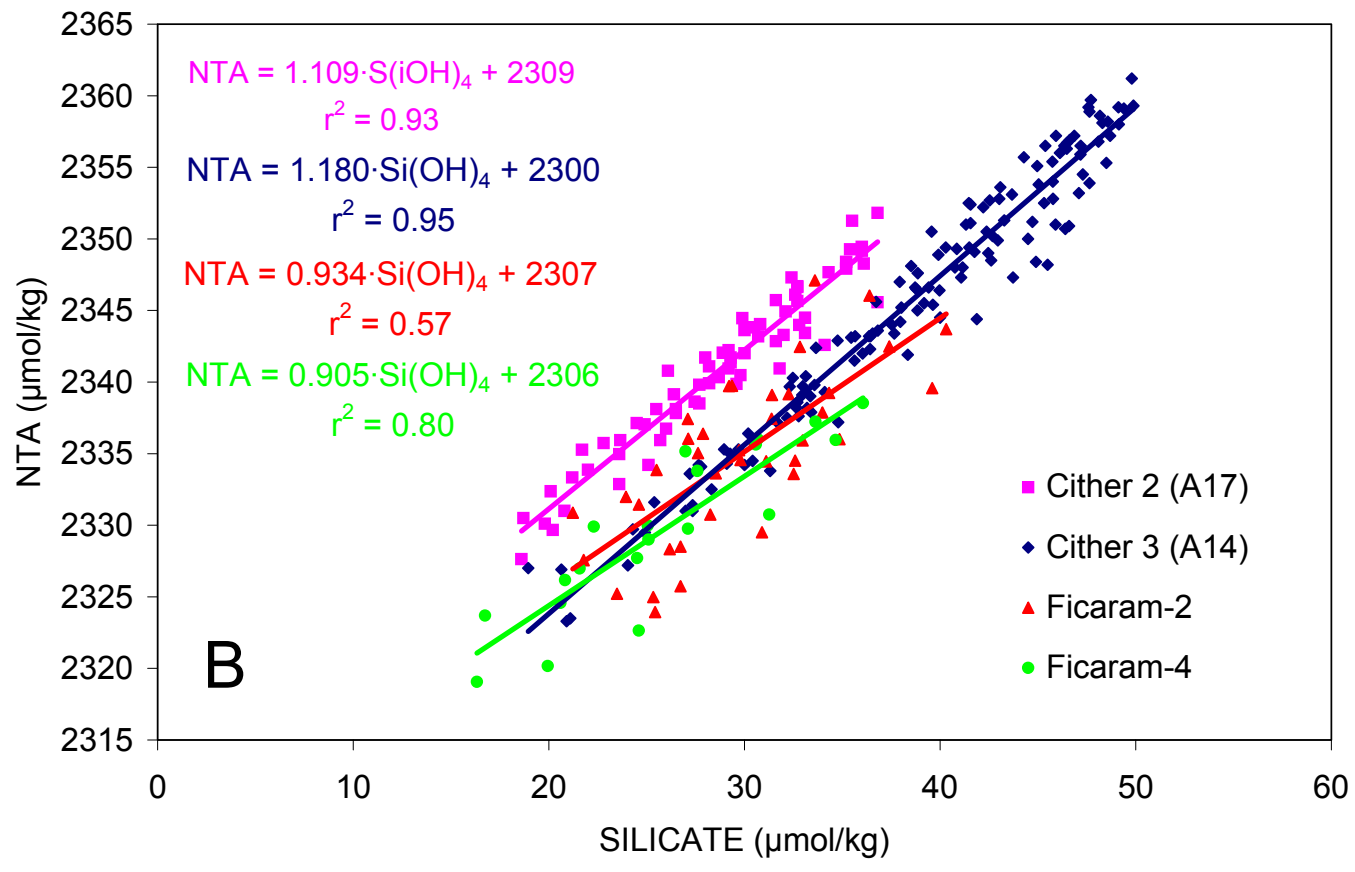

Fig. 3.3. Relationship between normalized TALK (NTA) and silicate, both in $\mu \mathrm{mol} / \mathrm{kg}$, for the cruises CITHER-2, CITHER-3, FICARAM-2, and FICARAM-4. (A) Between $3^{\circ} \mathrm{S}$ and $29^{\circ} \mathrm{S}$ at $1000-2000 \mathrm{dbar}$. (B) Between $9^{\circ} \mathrm{N}$ and $25^{\circ} \mathrm{S}$ at $2000-3000 \mathrm{dbar}$. 
the normalized TALK (NTA) data with regard to the silicate content among the four cruises. The upper graph presents the data comparison corresponding to the zone between $3^{\circ} \mathrm{S}$ and $29^{\circ} \mathrm{S}$ at $1000-2000 \mathrm{dbar}$. The lower graph exhibits the same kind of comparison but along the latitude $9^{\circ} \mathrm{N}$ to $25^{\circ} \mathrm{S}$ at 2000 3000 dbar. In both cases, the slopes NTA vs silicate of the three cruises CITHER-3, FICARAM-2 and FICARAM-4 are coincident, and the slope NTA vs silicate for CITHER-2 is higher and parallel to the others. Taking a concentration of silicate of $30 \mu \mathrm{mol} / \mathrm{kg}$, we find a difference of $8.0 \pm 0.6 \mu \mathrm{mol} / \mathrm{kg}$ in the zone $3^{\circ} \mathrm{S}-29^{\circ} \mathrm{S}$ and $7.7 \pm 1.1 \mu \mathrm{mol} / \mathrm{kg}$ in the zone $9^{\circ} \mathrm{N}-25^{\circ} \mathrm{S}$.

The comparison made with recent cruises is coincident with the internal consistency made by Wanninkhof et al. (2003) that suggested that A17 TALK was higher by $8 \mu \mathrm{mol} / \mathrm{kg}$. Therefore, a downward correction of $8 \mu \mathrm{mol} / \mathrm{kg}$ was applied to all the TALK values.

\section{$3.4 \mathrm{pH}$ Measurements}

For $\mathrm{pH}$ measurements, a Metrohm $654 \mathrm{pH}$ meter with a Metrohm 6.0233.100 combination glass electrode was used. The $\mathrm{pH}$ electrode was standardized in the same way as the alkalinity electrodes [NBS buffer at $\mathrm{pH} 7.413$ to calibrate, NBS buffer at $\mathrm{pH} 4.008$ to check calibration according to Pérez and Fraga (1987b), acclimatization in a $\mathrm{pH} 4.4$ seawater buffer]. The latter was made up in $1 \mathrm{~kg}$ of CO C $_{2}$-free seawater with $4.0846 \mathrm{~g}$ of $\mathrm{C}_{8} \mathrm{H}_{5} \mathrm{KO}_{4}$ and $1.52568 \mathrm{~g}$ of $\mathrm{B}_{4} \mathrm{O}_{7} \mathrm{Na}_{2}-10 \mathrm{H}_{2} \mathrm{O}$ (borax). The temperature measurement for each $\mathrm{pH}$ sample was done with a Pt-100 probe, and $\mathrm{pH}$ values were normalized to $15^{\circ} \mathrm{C}$. Changes in electrode response were corrected in the same manner as for alkalinity using titration curves generated at the end of the cruise in seawater $(\mathrm{S}=34.655)$ with $\mathrm{HCl}$ at $25.7^{\circ} \mathrm{C}$. The resulting correction factor for $\mathrm{pH}$ was $0.026 \pm 0.001$, which was added to the $\mathrm{pH}$ analyses. The precision of the $\mathrm{pH}$ determination was assessed from 186 pairs of samples collected from two rosette bottles closed at the same depth in the same way as for TALK. The precision of the determination was $0.002 \pm 0.003$.

\subsection{Underway $\mathrm{pCO}_{2}$ Measurements}

Surface $\mathrm{pCO}_{2}$ was measured continuously using a shower-type equilibrator with detection of $\mathrm{CO}_{2}$ by an infrared analyzer according to a design and techniques reported by Broecker and Takahashi (1966). Partial pressures of $\mathrm{CO}_{2}$ in the surface seawater have been computed from the $\mathrm{CO}_{2}$ concentration measured in dried equilibrated air in the following manner. The pressure of equilibration, reduced by the vapor pressure of water (computed at the equilibrator temperature) was applied to the $\mathrm{CO}_{2}$ concentration to yield the $\mathrm{pCO}_{2}$ at equilibrator temperature. This value was then adjusted to the sea surface temperature using the relationship given by Takahashi et al. (1993) and expressed in units of microatmospheres ( $\mu \mathrm{atm})$. The R/V Maurice Ewing was not equipped with a thermosalinograph at the time of this cruise. Surface temperature was measured by means of a pair of thermistors attached to the keel. These thermistors were calibrated in place against a thermometer traceable to NIST. The resolution of the device used to read the thermistor was $0.1^{\circ} \mathrm{C}$. These data will likely be combined with other surface $\mathrm{pCO}_{2}$ data from the Atlantic Ocean to form a separate report and will not be discussed further here.

\subsection{Internal Consistency Checks}

The $\mathrm{pH}$ values have a good precision, as shown by the reproducibility $(0.002 \pm 0.003)$ of the 186 pairs of samples collected from two rosette bottles closed at the same depth. During the cruise, surface seawater stored in 25-L plastic containers was used as $\mathrm{pH}$ "quasi-steady" seawater sub-standard (SSS). At each station, the $\mathrm{pH}$ of this SSS was measured before and after each series of samples, but samples of CRM were not analyzed. Therefore, the $\mathrm{pH}$ data could be displaced with respect to one station to other. The 
internal consistency comparison made in Wanninkhof et al. (2003) between measured and calculated (from TALK and $\mathrm{pH}$ ) $\mathrm{TCO}_{2}$ showed a bias. They suspect that the calculation involving $\mathrm{pH}$ is the culprit.

Consequently, to correct the deviations of $\mathrm{pH}$ between stations, we carried out an internal consistency check using the CRM-referenced $\mathrm{TCO}_{2}$ and TALK data and the fugacity of $\mathrm{CO}_{2}\left(f \mathrm{CO}_{2}\right)$ in surface waters. The first step to check if there is an offset is to compare the variations of $f \mathrm{CO}_{2}$ (calculated - measured) in surface waters $\left(\triangle f \mathrm{CO}_{2}\right)$ with the variations of the average $\mathrm{TCO}_{2}$ (calculated - measured) of water column data $\left(\Delta \mathrm{TCO}_{2}\right)$. Figure 3.4 shows a negative and significant correlation $\left(\mathrm{r}^{2}=0.39\right)$ between $\Delta f \mathrm{CO}_{2}$ and $\Delta \mathrm{TCO}_{2}$, which means that there is a $\mathrm{pH}$ bias between stations.

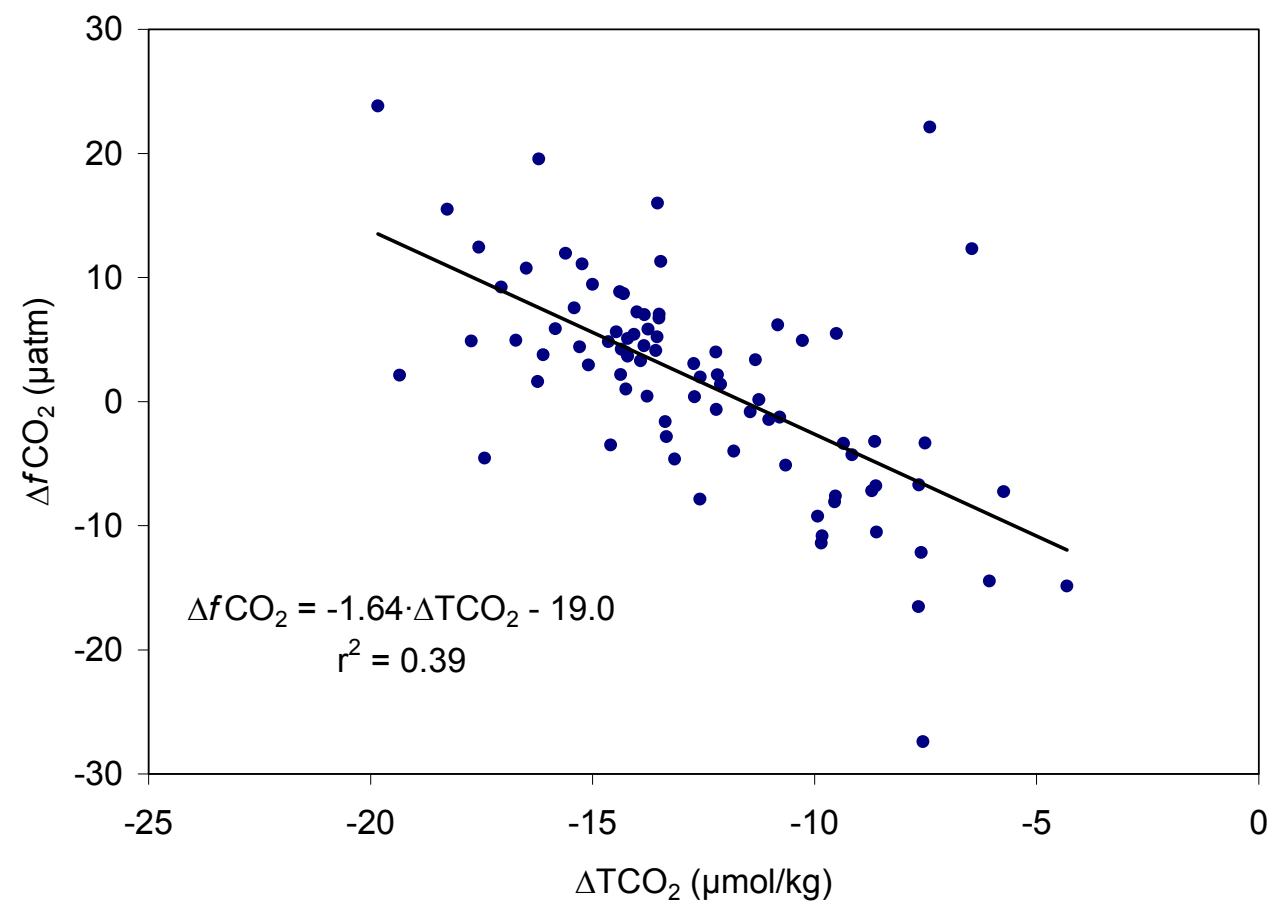

Fig. 3.4. Relationship between variations of $\mathrm{fCO}_{2}$ (calculated - measured) in surface waters $\left(\triangle \mathrm{CCO} \mathrm{O}_{2}\right)$ and variations of the average $\mathrm{TCO}_{2}$ (calculated - measured) of water column data $\left(\Delta \mathrm{TCO}_{2}\right)$.

The correction of $\mathrm{pH}$ was made using the surface data of calculated $\mathrm{pH}$ from measured $f \mathrm{CO}_{2}$ and $\mathrm{TCO}_{2}$. In all cases the dissociation constants of Mehrbach et al. (1973) as modified by Lueker et al. (2000) were used. After $\mathrm{pH}$ values were corrected, the relationship between variations of $f \mathrm{CO}_{2}$ (calculated - measured) and variations of the average $\mathrm{TCO}_{2}$ (calculated - measured) did not show any correlation $\left(\mathrm{r}^{2}=0.002\right)$, indicating that the bias had disappeared.

Once $\mathrm{pH}$ values were corrected, $\mathrm{TCO}_{2}$ was calculated from $\mathrm{pH}$ and TALK and compared with the measured $\mathrm{TCO}_{2}$. Figure 3.5 is a plot of the coulometrically measured $\mathrm{TCO}_{2} \mathrm{vs}^{\mathrm{TCO}_{2}}$ derived from the TALK and $\mathrm{pH}$ measurements made on the A17 section. This plot shows a high regression $\left(\mathrm{r}^{2}=0.997\right.$; $\mathrm{p}<0.0001$ ) with an average error of the estimate of $\pm 2.8 \mu \mathrm{mol} / \mathrm{kg}$ and a slope very close to unit $(1.0088 \pm 0.0011)$. The average difference between calculated and measured $\mathrm{TCO}_{2}$ during the cruise was $4.3 \pm 2.9 \mu \mathrm{mol} / \mathrm{kg}$. 


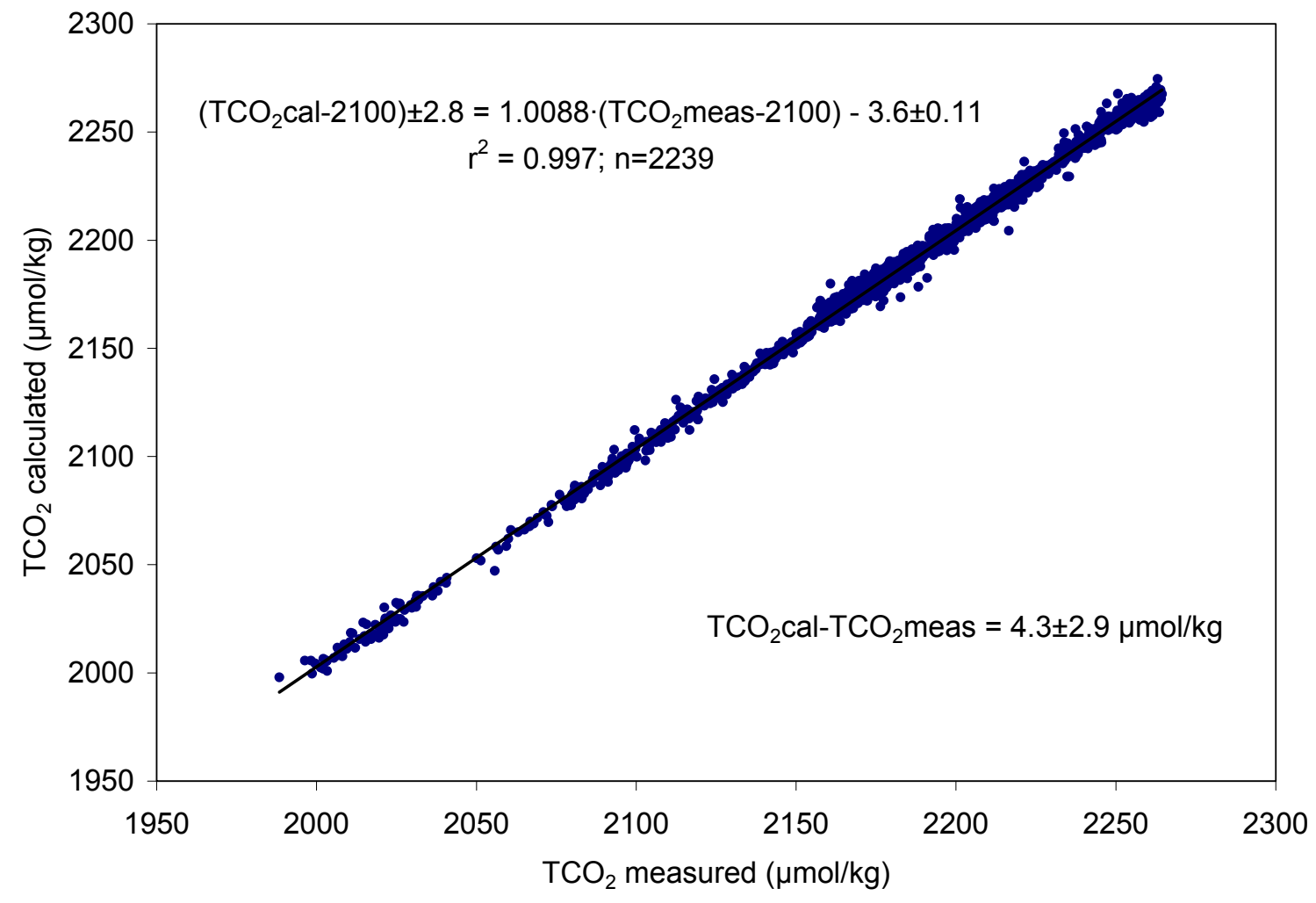

Fig. 3.5. Relationship between measured and calculated $\mathrm{TCO}_{2}$ from TALK and $\mathrm{pH}$ using the dissociation constants given by Lueker et al. (2000).

Figure 3.6 compares the $f \mathrm{CO}_{2}$ underway measured and $f \mathrm{CO}_{2}$ calculated from surface TALK and $\mathrm{pH}$ data waters obtained during the A17 cruise. There is a high regression $\left(r^{2}=0.992, p<0.0001\right)$ with an average error of the estimate of $\pm 3.1 \mu \mathrm{atm}$ and a slope close to unity $(1.0055 \pm 0.0066)$. The average difference between calculated and measured $\mathrm{pCO}_{2}$ was $-2.1 \pm 3.1 \mu \mathrm{atm}$.

After the TALK and $\mathrm{pH}$ corrections, the regressions between both measured and calculated $\mathrm{TCO}_{2}$ and $f \mathrm{CO}_{2}$ are higher $\left(\mathrm{r}^{2}=0.997, \mathrm{r}^{2}=0.992\right.$, respectively) than those obtained by Ríos and Pérez (1999) using the original dissociation constants of Mehrbach et al. (1973) $\left[\mathrm{r}^{2}=0.990, \mathrm{r}^{2}=0.966\right.$, respectively $]$. Also, their slopes are closer to unity in both cases (1.00088 vs 1.024 for $\mathrm{TCO}_{2}$ and $1.0055 \mathrm{vs} 0.899$ for $\left.f \mathrm{CO}_{2}\right)$, and the average error of their estimates decreases from \pm 4.4 to $\pm 2.8 \mu \mathrm{mol} / \mathrm{kg}$ for $\mathrm{TCO}_{2}$ and from \pm 6 to $\pm 3.1 \mu \mathrm{atm}$ for $f \mathrm{CO}_{2}$.

\subsection{Recommendations}

In the light of the comparison of the TALK data with other cruises and the analysis of the internal consistency among the four variables of carbon system measured during the A17 section, we would suggest to apply the following corrections for the data in the CDIAC database:

1. According to the comparison between TALK measured on A17 and recent cruises (CITHER-3, FICARAM-2, and FICARAM-3), a downward correction of $8 \mu \mathrm{mol} / \mathrm{kg}$ is proposed for TALK.

2. Based on the internal consistency check carried out among the four carbon system variables, we propose to modify the $\mathrm{pH}$ measurements adding by stations the values gathered in Table 3.8. 


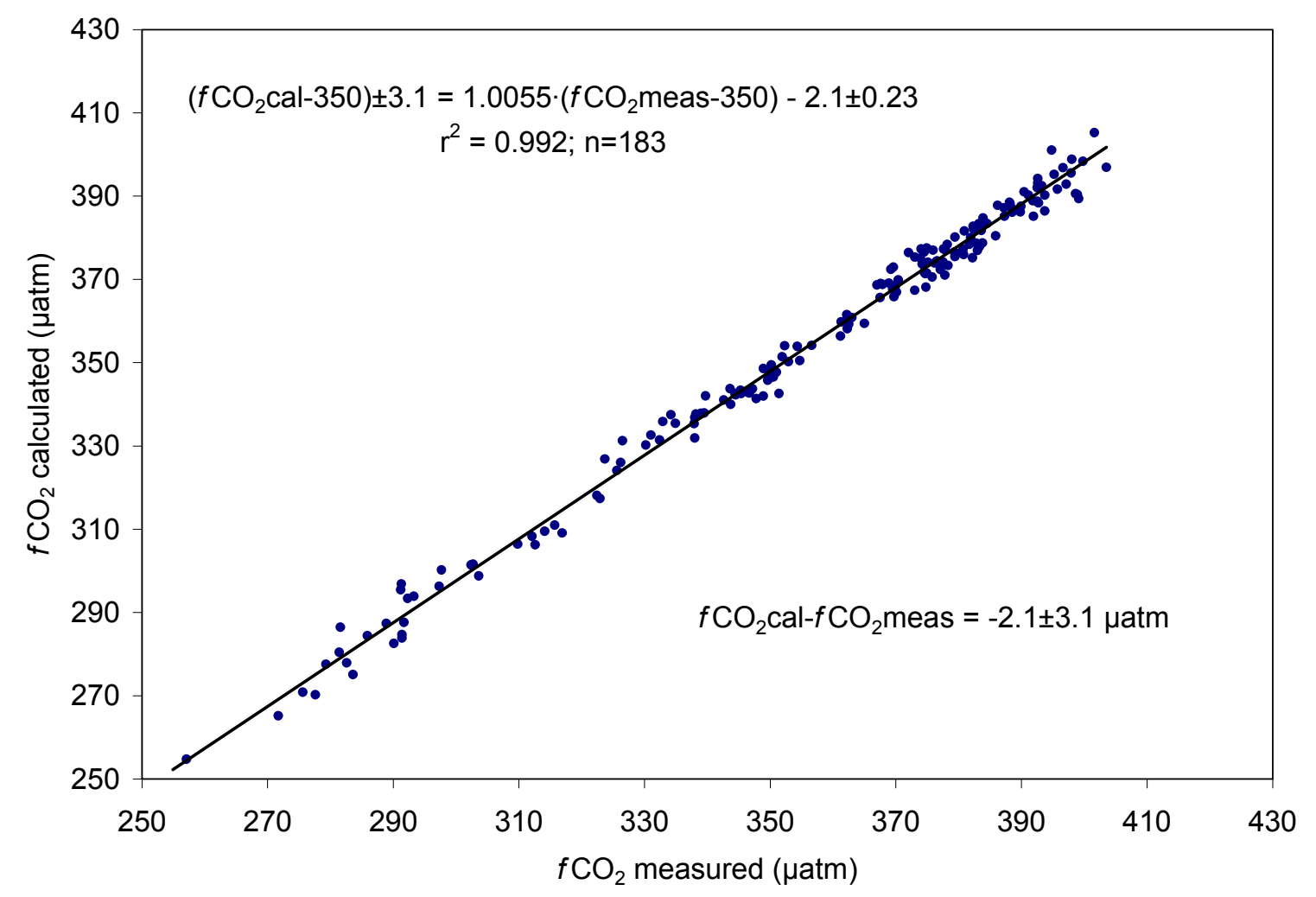

Fig. 3.6. Relationship between $\ell \mathrm{CO}_{2}$ measured and $\ell \mathrm{CO}_{2}$ calculated from TALK and pH using the dissociation constants given by Lueker et al. (2000).

Table 3.8. Recommended corrections for $\mathrm{pH}$ values measured during the WOCE section 17

\begin{tabular}{|c|c||c|c||c|c||c|c||c|c|}
\hline Station & $\Delta \mathrm{pH}$ & Station & $\Delta \mathrm{pH}$ & Station & $\Delta \mathrm{pH}$ & Station & $\Delta \mathrm{pH}$ & Station & $\Delta \mathrm{pH}$ \\
\hline 3 & 0.003 & 49 & 0.007 & 95 & -0.007 & 143 & 0.001 & 189 & 0.005 \\
4 & 0.013 & 50 & 0.012 & 96 & -0.003 & 144 & 0.001 & 190 & 0.005 \\
5 & 0.011 & 51 & 0.009 & 97 & -0.007 & 145 & 0.011 & 191 & 0.007 \\
6 & 0.003 & 52 & 0.003 & 98 & -0.007 & 146 & -0.007 & 192 & 0.007 \\
7 & 0.018 & 53 & 0.003 & 99 & -0.006 & 147 & 0.007 & 193 & 0.003 \\
8 & 0.006 & 54 & 0.007 & 100 & -0.007 & 148 & 0.007 & 194 & 0.007 \\
9 & 0.033 & 55 & 0.003 & 101 & -0.009 & 149 & 0.005 & 195 & -0.001 \\
10 & 0.023 & 56 & 0.003 & 102 & -0.001 & 150 & -0.003 & 196 & -0.005 \\
11 & 0.028 & 57 & 0.013 & 103 & -0.011 & 151 & -0.007 & 197 & -0.001 \\
12 & 0.013 & 58 & 0.003 & 104 & -0.011 & 152 & -0.007 & 198 & 0.011 \\
13 & 0.013 & 59 & 0.003 & 105 & -0.012 & 153 & -0.007 & 199 & 0.009 \\
14 & 0.003 & 60 & 0.011 & 106 & -0.009 & 154 & -0.005 & 200 & 0.009 \\
15 & 0.017 & 61 & 0.017 & 107 & -0.009 & 155 & -0.007 & 201 & 0.009 \\
16 & 0.013 & 62 & 0.011 & 108 & -0.002 & 156 & -0.007 & 202 & 0.009 \\
17 & 0.019 & 63 & 0.005 & 109 & -0.009 & 157 & 0.003 & 203 & 0.009 \\
18 & 0.019 & 64 & 0.011 & 110 & -0.009 & 158 & 0.003 & 204 & 0.009 \\
19 & 0.011 & 65 & 0.011 & 111 & -0.007 & 159 & 0.003 & 205 & 0.009
\end{tabular}


Table 3.8 (continued)

\begin{tabular}{|c|c||c|c||c|c||c|c||c|c|}
\hline Station & $\Delta \mathrm{pH}$ & Station & $\Delta \mathrm{pH}$ & Station & $\Delta \mathrm{pH}$ & Station & $\Delta \mathrm{pH}$ & Station & $\Delta \mathrm{pH}$ \\
\hline 20 & 0.009 & 66 & 0.011 & 112 & -0.009 & 160 & 0.003 & 206 & 0.009 \\
21 & 0.023 & 67 & 0.015 & 113 & -0.009 & 161 & 0.007 & 207 & 0.007 \\
22 & 0.021 & 68 & 0.017 & 114 & -0.003 & 162 & 0.007 & 208 & 0.007 \\
23 & 0.017 & 69 & 0.007 & 115 & -0.005 & 163 & 0.001 & 209 & 0.007 \\
24 & 0.011 & 70 & 0.007 & 118 & 0.008 & 164 & 0.003 & 210 & 0.007 \\
25 & -0.002 & 71 & 0.003 & 119 & 0.008 & 165 & -0.003 & 212 & -0.003 \\
26 & 0.005 & 72 & 0.005 & 120 & 0.015 & 166 & 0.011 & 213 & 0.003 \\
27 & 0.017 & 73 & 0.001 & 121 & 0.003 & 167 & 0.001 & 214 & 0.003 \\
28 & 0.015 & 74 & 0.003 & 122 & 0.015 & 168 & 0.001 & 215 & -0.001 \\
29 & 0.017 & 75 & -0.005 & 123 & 0.003 & 169 & 0.003 & 216 & 0.003 \\
30 & 0.019 & 76 & 0.003 & 124 & 0.015 & 170 & 0.003 & 217 & 0.003 \\
31 & 0.013 & 77 & 0.003 & 125 & 0.003 & 171 & 0.001 & 218 & -0.007 \\
32 & 0.003 & 78 & 0.006 & 126 & -0.001 & 172 & -0.007 & 219 & 0.003 \\
33 & 0.009 & 79 & 0.001 & 127 & 0.003 & 173 & -0.009 & 220 & 0.009 \\
34 & 0.009 & 80 & 0.001 & 128 & 0.003 & 174 & -0.007 & 221 & 0.003 \\
35 & -0.001 & 81 & 0.001 & 129 & 0.003 & 175 & -0.001 & 222 & 0.003 \\
36 & 0.011 & 82 & -0.005 & 130 & 0.003 & 176 & 0.002 & 223 & 0.006 \\
37 & 0.013 & 83 & 0.001 & 131 & 0.005 & 177 & 0.007 & 224 & 0.003 \\
38 & 0.003 & 84 & -0.009 & 132 & 0.003 & 178 & 0.007 & 225 & 0.003 \\
39 & 0.003 & 85 & -0.009 & 133 & 0.003 & 179 & 0.013 & 226 & 0.001 \\
40 & -0.007 & 86 & -0.009 & 134 & 0.003 & 180 & 0.007 & 227 & 0.003 \\
41 & 0.003 & 87 & -0.014 & 135 & -0.005 & 181 & 0.007 & 228 & 0.007 \\
42 & 0.003 & 88 & -0.009 & 136 & 0.003 & 182 & -0.003 & 229 & 0.003 \\
43 & 0.003 & 89 & -0.009 & 137 & 0.003 & 183 & -0.003 & 230 & 0.006 \\
44 & -0.011 & 90 & -0.007 & 138 & 0.003 & 184 & -0.011 & 231 & 0.003 \\
45 & -0.007 & 91 & -0.015 & 139 & 0.003 & 185 & -0.006 & 232 & 0.008 \\
46 & 0.005 & 92 & -0.007 & 140 & 0.009 & 186 & -0.009 & 233 & 0.003 \\
47 & 0.011 & 93 & -0.001 & 141 & 0.003 & 187 & -0.001 & 234 & 0.003 \\
48 & 0.007 & 94 & 0.003 & 142 & 0.003 & 188 & 0.005 & 235 & 0.003 \\
\hline
\end{tabular}





\section{HOW TO OBTAIN THE DATA AND DOCUMENTATION}

This database (NDP-084) is available free of charge from CDIAC. The complete documentation and data can be obtained from the CDIAC oceanographic Web site (http://cdiac.ornl.gov/oceans/ doc.html), through CDIAC's online ordering system (http://cdiac.ornl.gov/pns/how_order.html), or by contacting CDIAC.

The data are also available from CDIAC's anonymous file transfer protocol (FTP) area via the Internet. Please note that your computer needs to have FTP software loaded on it. (This is built in to most newer operating systems.) Use the following commands to obtain the database.

ftp cdiac.ornl.gov or $>$ ftp 160.91.18.18

Login: "anonymous" or "ftp"

Password: your e-mail address

ftp $>$ cd pub/ndp084/

ftp $>$ dir

ftp $>$ mget (files)

$\mathrm{ftp}>$ quit

Contact information:

Carbon Dioxide Information Analysis Center

Oak Ridge National Laboratory

P.O. Box 2008

Oak Ridge, Tennessee 37831-6335

USA

Telephone: (865) 574-3645

Telefax: (865) 574-2232

E-mail: cdiac@ornl.gov

Internet: http://cdiac.ornl.gov/ 



\section{REFERENCES}

Álvarez, M., A. F. Ríos, F. F. Pérez, H. L. Bryden, and G. Rosón. 2003. Transports and budgets of total inorganic carbon in the subpolar and temperate North Atlantic. Global Biogeochemical Cycles 17 (1): 1029.

Álvarez-Salgado, X. A., F. Fraga, and F. F. Pérez. 1992. Determination of nutrient salts both in sea and brackish waters by automatic methods. The phosphate blank. Marine Chemistry 39:311-319.

Billant, A. 1985. Calibration des mesures d'une sonde CTD-O ${ }_{2}$ Neil-Brown, Rapport Scientifique et Technique de l'IFREMER, no. 1.

Brewer, P. G., C. Goyet, and D. Dyrssen. 1989. Carbon dioxide transport by ocean currents at $25^{\circ} \mathrm{N}$ latitude in the Atlantic Ocean. Science 246:477-79.

Brown, N., and G. K. Morrison. 1978. WHOI/Brown Conductivity, Temperature, and Depth Profiler. Woods Hole Oceanographic Institute Technical Report No. WHOI-78-23.

Bryden, H. L., and M. M. Hall. 1980. Heat transport by ocean currents across $25^{\circ} \mathrm{N}$ latitude in the North Atlantic Ocean. Science 207:884.

Culberson, C. H. 1981. Direct potentiometry in marine electrochemistry. In Marine Electrochemistry. Ed. M. Whitfield and D. Jagner. Chichester: John Wiley.

Culberson, C. H., and S. Huang. 1987. An automated amperometric oxygen titration. Deep Sea Research $34: 875-80$.

Culberson, C. H., and R. T. Williams. 1991. A Comparison of Methods for the Determination of Dissolved Oxygen in Seawater. WHP Office Report, WHPO 91-2.

DOE (U.S. Department of Energy). 1994. Handbook of Methods for the Analysis of the Various Parameters of the Carbon Dioxide System in Seawater. Version 2.0. ORNL/CDIAC-74. Ed. A. G. Dickson and C. Goyet. Carbon Dioxide Information Analysis Center, Oak Ridge National Laboratory, Oak Ridge, Tenn.

Groupe CITHER-2, Le. 1996. Recueil de données, campagne CITHER-2, R/V Maurice Ewing (4 janvier21 mars 1994). Volume 3: Traceurs Géochimiques. Rapport Interne LPO 96-02.

Hansen, H. P., and K. Grasshoff. 1983. Automated chemical analysis. In Methods of Seawater Analysis. Ed. K. Grasshof et al. Verlag Chemie 3347-95.

Holfort, J., K. M. Johnson, B. Schneider, G. Siedler, and D. W. R. Wallace. 1998. The meridional transport of dissolved inorganic carbon in the South Atlantic Ocean. Global Biochemical Cycles 12:479-99.

Huffman, E. W. D., Jr. 1977. Performance of a new automatic carbon dioxide coulometer. Microchemical Journal 22:567-73.

Johnson, K. M., A. E. King, and J. McN. Sieburth. 1985. Coulometric $\mathrm{TCO}_{2}$ analyses for marine studies: An introduction. Marine Chemistry 16:61-82. 
Johnson, K. M., J. McN. Sieburth, P. J. LeB. Williams, and L. Braendstroem. 1987. Coulometric $\mathrm{TCO}_{2}$ analysis for marine studies: Automation and calibration. Marine Chemistry 21:117-33.

Johnson, K. M., and D.W.R. Wallace. 1992. The single-operator multiparameter metabolic analyzer for total carbon dioxide with coulometric detection. DOE Research Summary no. 19. Carbon Dioxide Information Analysis Center, Oak Ridge National Laboratory, Oak Ridge, Tenn.

Johnson, K. M., K. D. Wills, D. B. Butler, W. K. Johnson, and C. S. Wong. 1993. Coulometric total carbon dioxide analysis for marine studies: Maximizing the performance of an automated gas extraction system and coulometric detector. Marine Chemistry 44:167-87.

Johnson, K. M., B. Schneider, L. Mintrop, and D. W. R. Wallace. 1998a. Carbon Dioxide, Hydrographic, and Chemical Data Obtained During the R/V Meteor Cruise 22/5 in the South Atlantic Ocean (WOCE Section A10, December 1992-January 1993). ORNL/CDIAC-113, NDP-066. Carbon Dioxide Information Analysis Center, Oak Ridge National Laboratory, Oak Ridge, Tenn.

Johnson, K. M., A. G. Dickson, G. Eischeid, C. Goyet, P. Guenther, R. M. Key, F. J. Millero, D. Purkerson, C. L. Sabine, R. G. Schotle, D. W. R. Wallace, R. J. Wilke, and C. D. Winn. 1998b. Coulometric total carbon dioxide analysis for marine studies: Assessment of the quality of total inorganic carbon measurements made during the U.S. Indian Ocean $\mathrm{CO}_{2}$ Survey, 1994-1996. Marine Chemistry 63:21-37.

Lueker, T. J., A. G. Dickson, and C. D. Keeling. 2000. Ocean $\mathrm{pCO}_{2}$ calculated from dissolved inorganic carbon, alkalinity and equations for $\mathrm{K}_{1}$ and $\mathrm{K}_{2}$ : Validations based on laboratory measurements of $\mathrm{CO}_{2}$ in gas and seawater at equilibrium. Marine Chemistry 70:105-19.

Mehrbach, C., C. H. Culberson, J. E. Hawley, and R. M. Pytkowicz. 1973. Measurements of the apparent dissociation constant of carbonic acid in seawater at atmospheric pressure. Limnology and Oceanography 18:897-907.

Mémery, L., M. Arhan, X. A. Alvarez-Salgado, M.-J. Messias, H. Mercier, G. C. Castro, and A. F. Ríos. 2000. The water masses along the western boundary of the south and equatorial Atlantic. Progress in Oceanography, 47:69-98.

Millero, F. J., and A. Poisson. 1981. International one-atmosphere equation of state for sea water. DeepSea Research 28:625-29.

Mouriño, C., and F. Fraga. 1985. Determinacion de nitratos en agua de mar. Investigación Pesquera 49:81-96.

Pérez, F. F., and F. Fraga. 1987a. The pH measurements in seawater on NBS scale. Marine Chemistry 21:315-27.

Pérez, F. F., and F. Fraga. 1987b. A precise and rapid analytical procedure for alkalinity determination. Marine Chemistry 21:169-82.

Ríos, A. F., and F. F. Pérez. 1999. Improvements in potentiometric determinations of the $\mathrm{CO}_{2}$ oceanic system using seawater sub-standards and $\mathrm{CO}_{2}$ reference materials. Ciencias Marinas 25(1):31-49. 
Ríos, A. F., X. A. Álvarez-Salgado, F. F. Pérez, L. S. Bingler, J. Arístegui, and L. Mémery. 2003. Carbon dioxide along WOCE line A14: Water masses characterization and anthropogenic entry. Journal of Geophysical Research 108 (C4): doi 10.1029/2000JC000366.

Roemmich, D., and C. Wunsch. 1985. Two transatlantic sections: Meridional circulation and heat flux in the subtropical North Atlantic Ocean. Deep Sea Research 32:619-64.

Rosón, G., A. F. Ríos, F. F. Pérez, A. Lavín, and H. L. Bryden. 2003. Carbon distribution, fluxes, and budgets in the subtropical North Atlantic Ocean $\left(24.5^{\circ} \mathrm{N}\right)$. Journal of Geophysical Research 108 (C5): doi 10.1029/1999JC000047.

Sabine, C. L., R. A. Feely, N. Gruber, R. M. Key, K. Lee, J. L. Bullister, R. Wanninkhof, C. S. Wong, D. W. R. Wallace, B. Tilbrook, F. J. Millero, T.-H. Peng, A. Kozyr, T. Ono, and A. F. Rios. 2004. The oceanic sink for anthropogenic $\mathrm{CO}_{2}$. Science 305:367-71.

Takahashi, T., J. Olafsson, J. G. Goddard, D. W. Chipman, and S. C. Sutherland. 1993. Seasonal variation of $\mathrm{CO}_{2}$ and nutrients in the high-latitude surface oceans: A comparative study. Global Biogeochemical Cycles 7:843-78.

Wallace, D. W. R. 2002. Storage and transport of excess $\mathrm{CO}_{2}$ in the oceans: The JGOFS/WOCE global $\mathrm{CO}_{2}$ survey. Pp. 489-521 in Ocean Circulation and Climate. Ed. J. Church, G. Siedler, and J. Gould. Academic Press.

Wanninkhof, R., T.-H. Peng, B. Huss, C. L. Sabine, and K. Lee. 2003. Comparison of Inorganic Carbon System Parameters Measured in the Atlantic Ocean from 1990 to 1998 and Recommended Adjustments. ORNL/CDIAC-140. Carbon Dioxide Information Analysis Center, Oak Ridge National Laboratory, Oak Ridge, Tenn.

Wilke, R. J., D. W. R. Wallace, and K. M. Johnson. 1993. A water-based, gravimetric method for the determination of gas sample loop volume. Analytical Chemistry 65:2403-6. 
